Prepared in cooperation with the New Hampshire Department of Environmental Services

\title{
Development and Evaluation of a Record Extension Technique for Estimating Discharge at Selected Stream Sites in New Hampshire
}

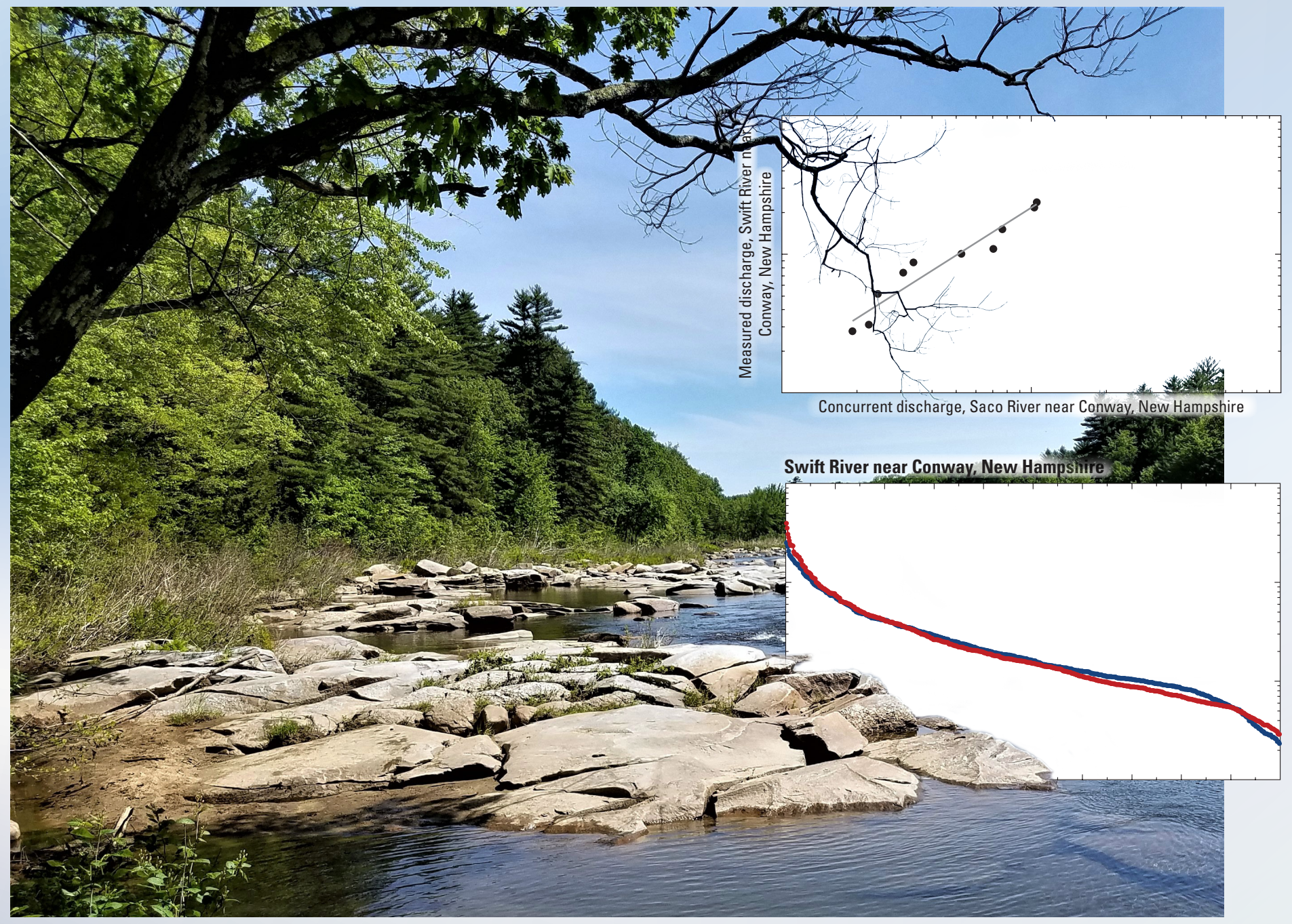

Scientific Investigations Report 2019-5066 
Cover. The Saco River near Conway, New Hampshire, viewed from U.S. Geological Survey reference streamgage 01064500 . Photograph by Jeremiah Pomerleau, U.S. Geological Survey. Graphs are modified from appendix figures 1.1 and 2.1. 


\section{Development and Evaluation of a Record Extension Technique for Estimating Discharge at Selected Stream Sites in New Hampshire}

By Scott A. Olson and Abraham J. Meyerhofer

Prepared in cooperation with the

New Hampshire Department of Environmental Services

Scientific Investigations Report 2019-5066 


\title{
U.S. Department of the Interior DAVID BERNHARDT, Secretary
}

\author{
U.S. Geological Survey \\ James F. Reilly II, Director
}

U.S. Geological Survey, Reston, Virginia: 2019

For more information on the USGS - the Federal source for science about the Earth, its natural and living resources, natural hazards, and the environment-visit https://www.usgs.gov or call 1-888-ASK-USGS.

For an overview of USGS information products, including maps, imagery, and publications, visit https://store.usgs.gov.

Any use of trade, firm, or product names is for descriptive purposes only and does not imply endorsement by the U.S. Government.

Although this information product, for the most part, is in the public domain, it also may contain copyrighted materials as noted in the text. Permission to reproduce copyrighted items must be secured from the copyright owner.

Suggested citation:

Olson, S.A., and Meyerhofer, A.J., 2019, Development and evaluation of a record extension technique for estimating discharge at selected stream sites in New Hampshire: U.S. Geological Survey Scientific Investigations Report 2019-5066, 23 p., https://doi.org/10.3133/sir20195066.

ISSN 2328-0328 (online) 


\section{Contents}

Abstract

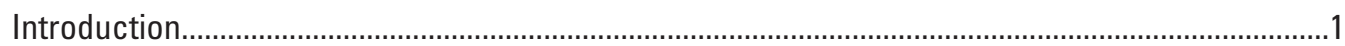

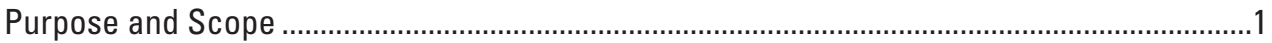

Description of Study Area ..................................................................................................2

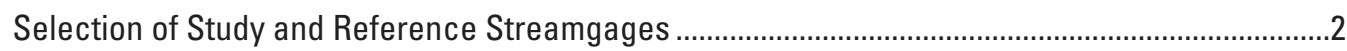

Generation of Estimated Records From the MOVE.1 Record Extension Technique ..........................7

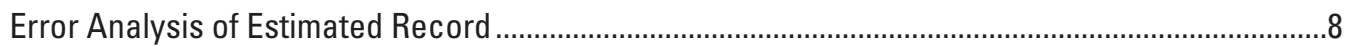

Comparison of Mean, Maximum, Minimum, and Standard Deviation ...................................... 9

Comparison of Flow-Duration Curves .......................................................................................

Accuracy of Entire Estimated Record ....................................................................................

Accuracy of Estimated Record for Low-Flow Regimes.........................................................11

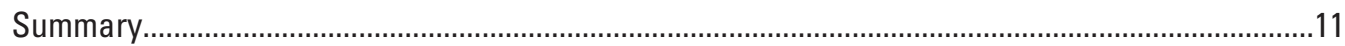

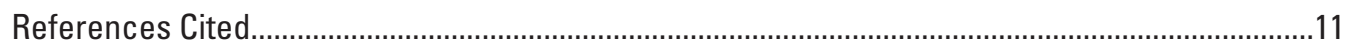

Appendix 1. Plots of Discharge Measurements at Study Streamgages and Concurrent

Daily Mean Discharge at Reference Streamgages..........................................................14

Appendix 2. Flow-Duration Curves of the Observed and Estimated Daily Mean Discharges at Study Streamgages ..........................................................................................................21

\section{Figures}

1. Map showing locations of six study streamgages and their drainage basins in New

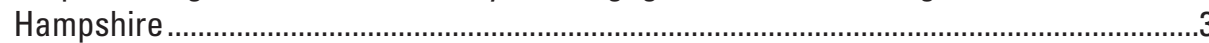

2. Map showing locations of reference streamgages and their drainage basins in New Hampshire and Vermont.............................................................................................5

\section{Tables}

1. Discontinued U.S. Geological Survey streamgages selected as study streamgages in New Hampshire

2. U.S. Geological Survey streamgages selected as reference streamgages in New Hampshire and Vermont.

3. Study streamgages and paired reference streamgages in New Hampshire and Vermont.

4. Dates of estimated discharge record generated for each of the study streamgages in New Hampshire.

5. Statistics of the observed and estimated daily mean discharge records for the six study streamgages in New Hampshire

6. Root-mean-square errors and the Nash-Sutcliffe efficiency coefficients of the maintenance of variance extension, type 1, equations for the six study streamgages in New Hampshire.

7. Percentage of days the estimated daily mean discharges were at or within 5,10 , 15,20 , and 25 percent of the concurrent observed daily mean discharges for six study streamgages in New Hampshire

8. Percentage of days the estimated daily mean discharges were within $5,10,15,20$, and 25 percent of the concurrent observed daily mean discharges when observed discharges were at or below the discharge exceeded 80 percent of the time for the six study streamgages in New Hampshire. 


\section{Conversion Factors}

U.S. customary units to International System of Units

\begin{tabular}{lcl}
\hline \multicolumn{1}{c}{ Multiply } & By & \multicolumn{1}{c}{ To obtain } \\
\hline inch (in.) & Length & \\
foot (ft) & 2.54 & centimeter $(\mathrm{cm})$ \\
mile (mi) & 0.3048 & meter $(\mathrm{m})$ \\
\hline & 1.609 & kilometer $(\mathrm{km})$ \\
\hline square mile $\left(\mathrm{mi}^{2}\right)$ & Area & \\
square mile $\left(\mathrm{mi}^{2}\right)$ & 259.0 & hectare $(\mathrm{ha})$ \\
\hline & 2.590 & square kilometer $\left(\mathrm{km}^{2}\right)$ \\
\hline cubic foot per second $\left(\mathrm{ft}^{3} / \mathrm{s}\right)$ & Flow rate & \\
\hline
\end{tabular}

Temperature in degrees Fahrenheit $\left({ }^{\circ} \mathrm{F}\right)$ may be converted to degrees Celsius $\left({ }^{\circ} \mathrm{C}\right)$ as ${ }^{\circ} \mathrm{C}=\left({ }^{\circ} \mathrm{F}-32\right) / 1.8$.

\section{Datum}

Horizontal coordinate information is referenced to the North American Datum of 1983 (NAD 83).

Vertical coordinate information is referenced to the North American Vertical Datum of 1988 (NAVD 88).

Elevation, as used in this report, refers to distance above the vertical datum.

\section{Abbreviations}

D80 daily mean discharge exceeded 80 percent of the time

MOVE.1 maintenance of variance extension, type 1

NWIS National Water Information System

RMSE root-mean-square error

SREF Streamflow Record Extension Facilitator

USGS

U.S. Geological Survey 


\title{
Development and Evaluation of a Record Extension Technique for Estimating Discharge at Selected Stream Sites in New Hampshire
}

\author{
By Scott A. Olson and Abraham J. Meyerhofer
}

\section{Abstract}

Daily mean discharges are needed for rivers in New Hampshire for the management of instream flows. It is impractical, however, to continuously gage all streams in New Hampshire, and at many sites where information is needed, the discharge data required do not exist. For such sites, techniques for estimating discharge are available. The U.S. Geological Survey, in cooperation with the New Hampshire Department of Environmental Services, developed and evaluated the accuracy of estimated discharge records for six discontinued U.S. Geological Survey streamgages in New Hampshire.

The estimated records were developed by using the maintenance of variance extension, type 1 (MOVE.1), record extension technique and were generated for periods with concurrent observed records to allow for evaluation. The six discontinued streamgages were on New Hampshire designated rivers throughout the State and had drainage areas ranging from 35.6 to 395 square miles with little to no regulation.

Estimated records for four of the six streamgages had Nash-Sutcliffe efficiency coefficients greater than 0.85 . The other two streamgages had Nash-Sutcliffe efficiency coefficients between 0.45 and 0.60 . For the four streamgages with the higher Nash-Sutcliffe efficiency coefficients, more than 35 percent of the estimated record was within 15 percent of the observed record. At the other two streamgages, more than 23 percent of the estimated record was within 15 percent of the observed record.

At lower discharges (exceeded 80 percent of the time), for four of the six streamgages, more than 40 percent of the estimated record was within 15 percent of the observed record. The site with the lowest Nash-Sutcliffe efficiency coefficient had more than 14 percent of the estimated record at low discharges within 15 percent of the observed record.

\section{Introduction}

Estimates of daily mean discharge are crucial for establishing the baseline information needed for planning and allocating water resources. As demands on discharge for withdrawals and diversions increase, it is critical to ensure that there is adequate discharge to meet various objectives, such as public water supply, agricultural and industrial water usage, recreation, and aquatic habitat protection. Typically, discharge statistics are determined from discharge data collected at U.S. Geological Survey (USGS) streamgages. However, it is impractical to continuously gage all streams in New Hampshire, and at many sites where information is needed, the discharge data required for determining discharge statistics do not exist. For such sites, record extension techniques can be used to estimate discharge. Record extension techniques can be used to relate discharges at the site of interest to concurrent discharges at a nearby long-term USGS streamgage (Matalas and Jacobs, 1964; Riggs, 1972; Hirsch, 1979, 1982).

Currently (as of 2019), daily mean discharge estimates are needed for 20 designated rivers in New Hampshire for the management of instream flows. A New Hampshire designated river is defined as a river that is managed and protected because of its outstanding natural and cultural resources (New Hampshire Department of Environmental Services, 2018). Evaluating the feasibility of estimating discharge records with record extension techniques provides insight into optimizing the development of a cost-effective streamgaging network for providing the data necessary to manage not only New Hampshire's rivers, but the Nation's rivers. The USGS, in cooperation with the New Hampshire Department of Environmental Services, developed estimated records for six discontinued streamgages throughout New Hampshire and assessed the estimated records' accuracy.

\section{Purpose and Scope}

This report documents the development and evaluation of estimated records of daily mean discharge generated by using the maintenance of variance extension, type 1 (MOVE.1), record extension technique (Hirsch, 1979, 1982). The report describes the selection of the study and reference streamgages and the generation of estimated records. Results are presented from the following evaluations of the estimated records' accuracy: comparisons between the estimated and observed 
records, root-mean-square errors and Nash-Sutcliffe efficiency coefficients of the MOVE.1 equations, and comparisons between estimated and observed daily mean discharges on a day-to-day basis. The results may be used to assess the merit of using record extension techniques in the State's management of rivers.

\section{Description of Study Area}

New Hampshire (fig. 1) comprises a land area of 9,304 square miles in the northeastern United States, nearly one-seventh of the total land area of New England. The State is approximately 175 miles long from north to south and ranges from about 100 miles wide from east to west at the southern end of the State to nearly 20 miles wide at its northern end. The southeastern corner of the State borders the Atlantic Ocean for 18 miles.

New Hampshire landscapes vary from lowlands along the Atlantic coastline to mountains with numerous peaks over 4,000 feet (relative to the North American Vertical Datum of 1988) in the north-central part of the State. Much of the remainder of New Hampshire consists of hilly topography and narrow river valleys. According to the National Land Cover Database (Homer and others, 2007), land cover classification in New Hampshire is approximately 78 percent forest, 8 percent developed land, 7 percent wetland, and 5 percent agricultural.

Four major rivers drain New Hampshire, and the State has about 40 rivers in total, with a stream network totaling 41,800 miles (New Hampshire State Library, 2018). New Hampshire has approximately 1,300 lakes or ponds, which account for 277 square miles (New Hampshire State Library, 2018). The largest lake is Lake Winnipesaukee (not shown), which covers an area of 71 square miles, in the central part of the State.

The climate of New Hampshire is temperate and humid with four distinct seasons. At the same time, New Hampshire is known for climatic extremes and rapid changes in weather. The mean annual air temperature ranges from about 41 degrees Fahrenheit $\left({ }^{\circ} \mathrm{F}\right)$ in the north to $46^{\circ} \mathrm{F}$ in the south (National Climatic Data Center, 2018). However, the historic range in temperature recorded in Concord, New Hampshire, is $-37^{\circ} \mathrm{F}$ to $102^{\circ} \mathrm{F}$.

Precipitation in the State is distributed evenly throughout the year and averages about 40 to 50 inches annually. Areas with high elevations may receive an additional 10 or more inches of precipitation annually. For example, the rain gage at 6,262 feet on Mount Washington receives an annual average of 97 inches of precipitation (National Climatic Data Center, 2018). Annual snowfall also varies across the State. Elevation has a strong effect on snowfall amounts. The coastline areas of New Hampshire receive about 50 inches of snowfall per year, and inland areas receive 60 to 80 inches. Mount Washington receives nearly 300 inches annually (U.S. Climate Data, 2018).

\section{Selection of Study and Reference Streamgages}

Six discontinued streamgages with drainage areas ranging from 35.6 to 395 square miles were selected as study streamgages for this investigation. These streamgages were selected because they were located on designated rivers. The six streamgages were in continuous operation for a minimum of 2 years and as many as 50 years. The number of field measurements of discharge at the streamgages ranged from 17 to 489 (fig. 1, table 1). The field measurements of discharge and the daily mean discharge data used from these streamgages can be found in the USGS National Water Information System (NWIS) database at https://waterdata.usgs.gov/nwis (U.S. Geological Survey, 2018).

For each study streamgage, one or more potential reference streamgages (also often referred to as index streamgages) were selected for record extension. These reference streamgages were active (as of 2018), and each had a period of record that overlapped that of the related study streamgage. The reference streamgages (fig. 2, table 2) were selected based on several factors: proximity to the paired study streamgage, similarity in drainage-basin characteristics, little to no regulation, strength and linearity of the correlation of daily mean discharge values with concurrent discharge measurements at the study streamgage, and length of record concurrent with that of the paired study streamgage. Some potential reference streamgages were rejected during the selection process. The reference streamgages and the corresponding study sites are shown in table 3 . All daily mean discharge data from the reference streamgages can be found in the USGS NWIS database (https://waterdata.usgs.gov/nwis).

Log-scale scatterplots of discharge measurements from the study sites and concurrent daily mean discharge values from the reference streamgages (appendix 1) were examined for linearity and outliers. Pearson's correlation coefficients of logarithmically transformed data, ranging from 0.863 to 0.968 , are shown in table 3 for the pairs of study and reference streamgages.

To assess the accuracy of the estimated discharges, the estimated record for each study streamgage was generated for a period concurrent with observed records at both the study and reference streamgages. Table 4 shows the dates of the estimated record for each of the six study streamgages. 


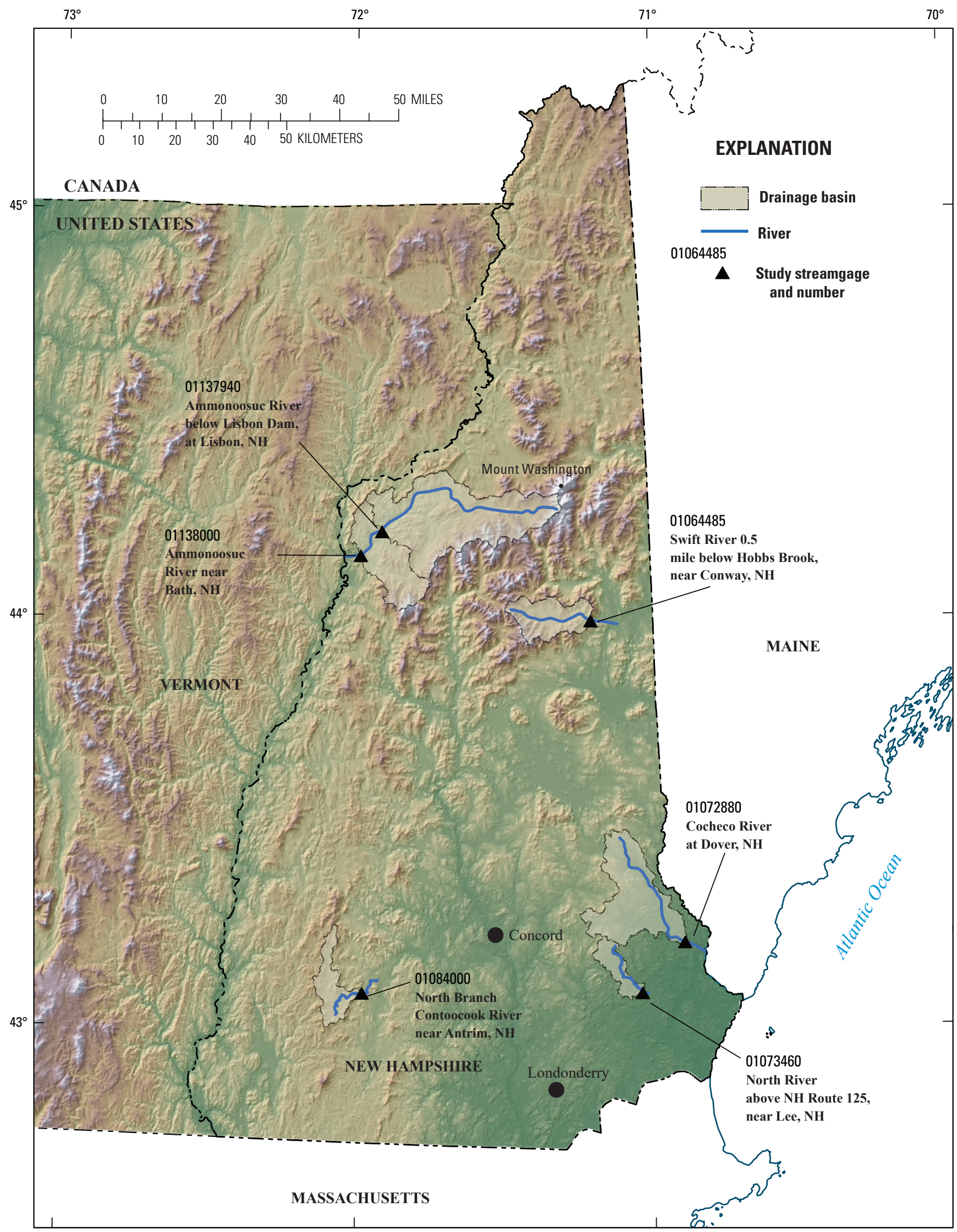

Base from U.S. Geological Survey and U.S. Census Bureau digital data

Shaded relief from U.S. Geological Survey National Elevation Dataset, 2007, 1/3-arc-second resolution

State boundaries from U.S. Census Bureau 2017 cartographic boundary file, 1:500,000 scale, 2017

Figure 1. Locations of six study streamgages and their drainage basins in New Hampshire. 
Table 1. Discontinued U.S. Geological Survey streamgages selected as study streamgages in New Hampshire.

[mi², square mile; NH, New Hampshire]

\begin{tabular}{clccl}
\hline $\begin{array}{c}\text { Streamgage } \\
\text { identification } \\
\text { number }\end{array}$ & \multicolumn{1}{c}{ Study streamgage } & $\begin{array}{c}\text { Drainage } \\
\text { area, } \\
\text { in mi }\end{array}$ & $\begin{array}{c}\text { Number of } \\
\text { available field } \\
\text { measurements } \\
\text { of discharge }\end{array}$ & $\begin{array}{c}\text { Period of } \\
\text { discharge record }\end{array}$ \\
\hline 01064485 & Swift River 0.5 mile below Hobbs Brook, near Conway, NH & 76.8 & 17 & $2009-11$ \\
01072880 & Cocheco River, at Spaulding Turnpike, at Dover, NH & 178 & 42 & $1991-96$ \\
01073460 & North River above NH Route 125, near Lee, NH & 35.6 & 30 & $2004-6$ \\
01084000 & North Branch Contoocook River near Antrim, NH & 54.8 & 489 & $1924-70,2009-11$ \\
01137940 & Ammonoosuc River below Lisbon Dam, at Lisbon, NH & 288 & 18 & $2009-11$ \\
01138000 & Ammonoosuc River near Bath, NH & 395 & 441 & $1935-80$ \\
\hline
\end{tabular}

Table 2. U.S. Geological Survey streamgages selected as reference streamgages in New Hampshire and Vermont.

[mi ${ }^{2}$, square mile; NH, New Hampshire; VT, Vermont]

\begin{tabular}{clcl}
\hline $\begin{array}{c}\text { Streamgage } \\
\text { identification } \\
\text { number }\end{array}$ & \multicolumn{1}{c}{ Reference streamgage } & $\begin{array}{c}\text { Drainage area, } \\
\text { in } \mathbf{~ m i}^{2}\end{array}$ & \multicolumn{1}{c}{ Period of discharge record } \\
\hline 01064500 & Saco River near Conway, NH & 385 & $1903-9,1929-2018$ \\
01072800 & Cocheco River near Rochester, NH & 85.7 & $1995-2018$ \\
01073000 & Oyster River near Durham, NH & 12.1 & $1934-2018$ \\
01075000 & Pemigewasset River at Woodstock, NH & 193 & $1939-77,2001-18$ \\
01076000 & Baker River near Rumney, NH & 143 & $1928-77,2001-18$ \\
01086000 & Warner River at Davisville, NH & 146 & $1939-78,2001-18$ \\
01130000 & Upper Ammonoosuc River near Groveton, NH & 232 & $1940-80,1982-2004,2010-18$ \\
01135500 & Passumpsic River at Passumpsic, VT & 436 & $1928-2018$ \\
01137500 & Ammonoosuc River at Bethlehem Junction, NH & 87.6 & $1940-2018$ \\
\hline
\end{tabular}




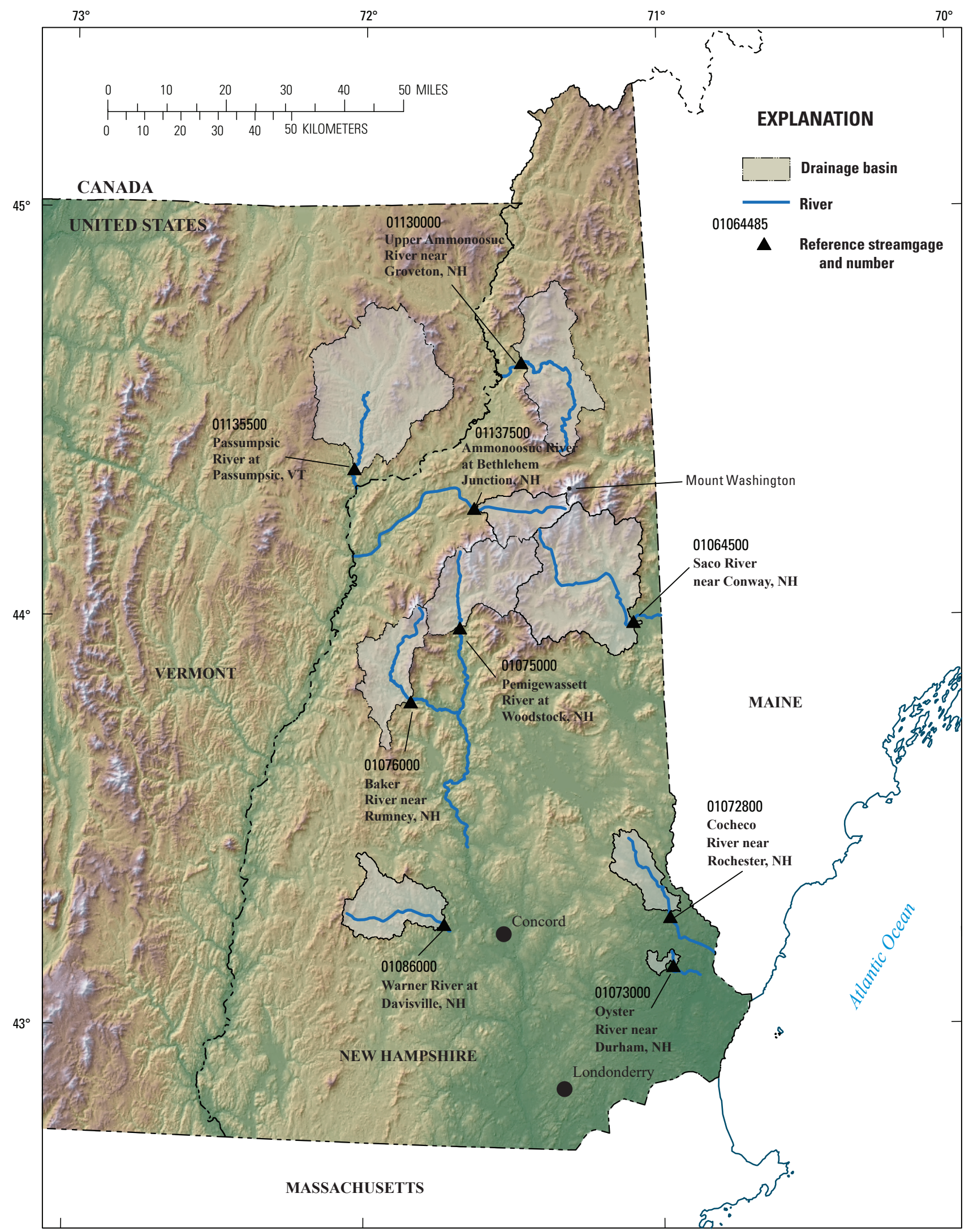

Base from U.S. Geological Survey and U.S. Census Bureau digital data

Shaded relief from U.S. Geological Survey National Elevation Dataset, 2007, 1/3-arc-second resolution

State boundaries from U.S. Census Bureau 2017 cartographic boundary file, 1:500,000 scale, 2017

Figure 2. Locations of reference streamgages and their drainage basins in New Hampshire and Vermont. 


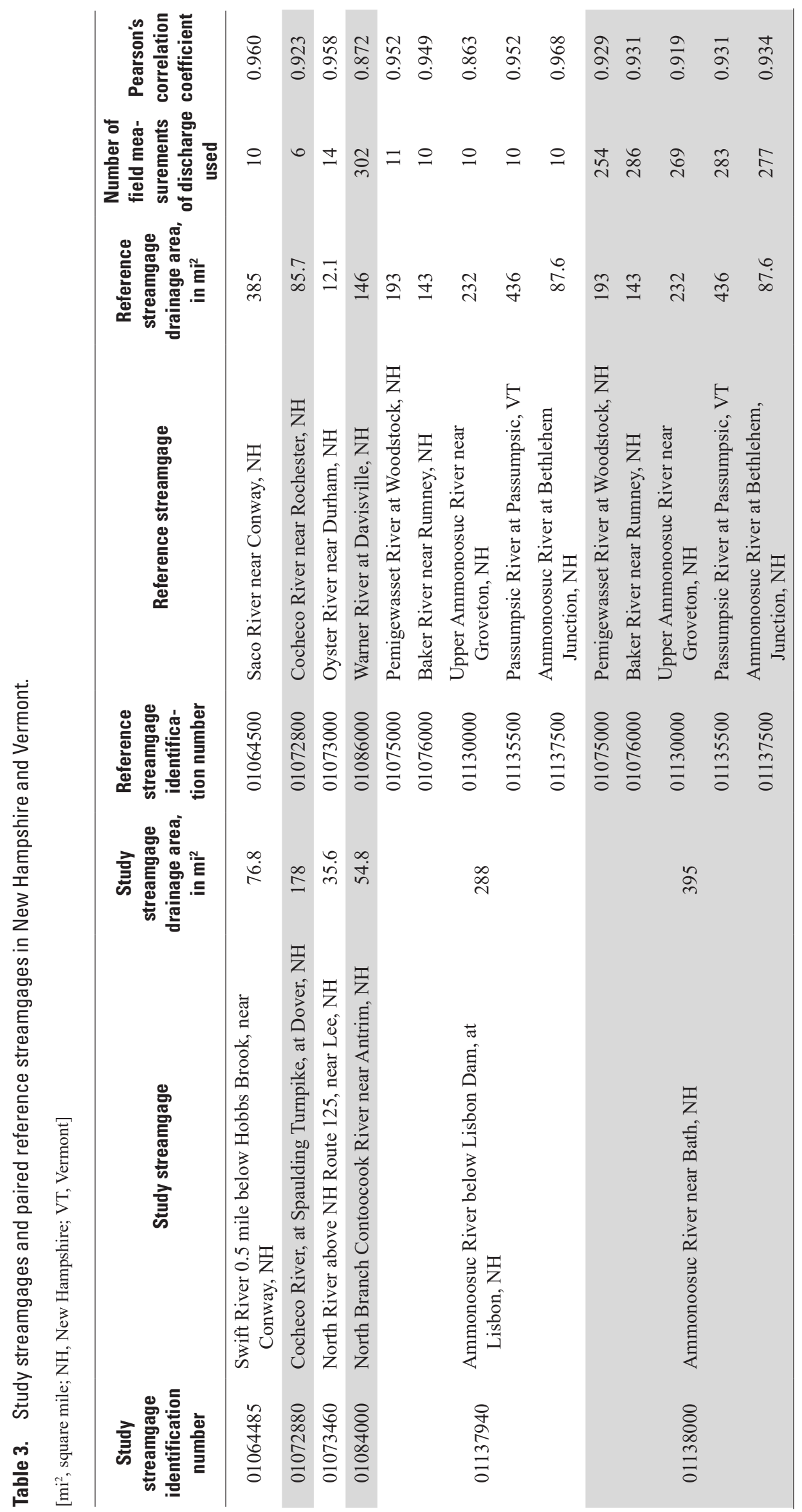


Table 4. Dates of estimated discharge record generated for each of the study streamgages in New Hampshire.

[NH, New Hampshire]

\begin{tabular}{llrl}
\hline $\begin{array}{c}\text { Streamgage } \\
\text { identifica- } \\
\text { tion number }\end{array}$ & \multicolumn{1}{c}{ Study streamgage } & \multicolumn{2}{c}{ Estimated discharge record } \\
\cline { 3 - 4 } & Number of & \\
days & Dates \\
\hline 01064485 & Swift River 0.5 mile below Hobbs Brook, near Conway, NH & 684 & August 29, 2009, to July 13, 2011 \\
01072880 & Cocheco River, at Spaulding Turnpike, at Dover, NH & 488 & March 1, 1995, to June 30, 1996 \\
01073460 & North River above NH Route 125, near Lee, NH & 844 & June 9, 2004, to September 30, 2006 \\
01084000 & North Branch Contoocook River near Antrim, NH & 11,991 & $\begin{array}{c}\text { October 1, 1939, to September 29, 1970, and } \\
\text { September 5, 2009, to July 5, 2011 }\end{array}$ \\
01137940 & Ammonoosuc River below Lisbon Dam, at Lisbon, NH & 741 & June 25, 2009, to July 5, 2011 \\
01138000 & Ammonoosuc River near Bath, NH & 13,565 & August 10, 1940, to September 29, 1977 \\
\hline
\end{tabular}

\section{Generation of Estimated Records From the MOVE.1 Record Extension Technique}

Record extension is a technique of estimating a record of discharge at a streamgage or stream location by using a relation between observed discharges at the streamgage or stream location and one or more reference streamgages. The techniques for estimating the daily mean discharge values at a site of interest using a reference streamgage typically involve linear regression. Ordinary least squares regression could be used; however, Hirsch (1982) found the MOVE.1 technique of regression had less bias when estimating discharge records.

Log-transformations of discharge data are commonly done to linearize discharge relations. Once the correlation of concurrent record between a study streamgage and a reference streamgage is evaluated and selected for use in record extension, the means and standard deviations of the log-transformations of the concurrent discharges are calculated. The MOVE.1 equation is then written as follows:

$$
Y_{i}=\bar{Y}+\frac{S_{y}}{S_{x}}\left(X_{i}-\bar{X}\right)
$$

where

$Y_{i} \quad$ is the estimated logarithm of the discharge at the study streamgage for day $i$,

$\bar{Y} \quad$ is the mean of the log-transformed observed discharges at the study streamgage,

$S_{y} \quad$ is the standard deviation of the logtransformed observed discharges at the study streamgage,

$S_{x} \quad$ is the standard deviation of the logtransformed observed discharges at the reference streamgage,
$X_{i} \quad$ is the log-transformed daily discharge at the reference streamgage for day $i$, and

$\bar{X} \quad$ is the mean of the log-transformed observed discharges at the reference streamgage.

As stated previously, the means and standard deviations used in the relation are for the concurrent record. To improve the linearity of the relation of the concurrent record, only discharge measurements at the study streamgages collected under base-flow conditions were used in the computations. Measurements made when discharges are high or rapidly changing often correlate poorly with daily mean discharges at reference streamgages. The base-flow-conditions criteria for selecting concurrent discharge measurements and daily mean discharge were that (1) study streamgage discharge measurements had to have gage height changes of 0.04 foot or less during the measurement and (2) the daily mean discharge at the reference streamgage could not decrease by more than 30 percent or increase by more than 10 percent from the previous day. This second criterion was adopted from base-flow criteria applied to similar hydrologic applications in New Jersey (Calarullo and others, 2018).

Other criteria recommended when defining a relation of concurrent discharge measurements to a reference streamgage are that the discharge has minimal to no regulation and that a minimum of eight total discharge measurements are available from different hydrologic recessions occurring in more than 1 year (Riggs, 1972). These criteria were applicable to all study streamgage relations except for the Cocheco River streamgage relation, which was based on only six measurements during one season of concurrent record.

The Streamflow Record Extension Facilitator (SREF) (Granato, 2009) was used to evaluate correlations, generate the MOVE. 1 equations for record extension, and compute the estimated daily records for the study sites. The SREF software was designed to help the user develop regression relations and implement them for discharge-record extension. 
For two of the study streamgages-Ammonoosuc River below Lisbon Dam (also known as Lower Lisbon Dam), at Lisbon, N.H., and Ammonoosuc River near Bath, N.H.-multiple reference streamgages were determined to be correlated to the study streamgage and were used to extend the record. This was done by determining a separate MOVE. 1 equation for each of the reference streamgages and determining the mean-square error between the discharge measurements and the estimated daily mean discharges on the dates of the measurements. The mean-square error was then used to weight the results determined from each of the reference streamgages. The weight was computed by

where

$$
\text { Weight }_{j}=\frac{\left(\sum_{j=1}^{N S} M S E_{j}\right)-M S E_{j}}{(N S-1)\left(\sum_{j=1}^{N S} M S E_{j}\right)},
$$

Weight ${ }_{j} \quad$ is the weighting factor for study streamgage $j$, $N S$ is the number of reference streamgages used, and

$M S E_{j} \quad$ is the mean-square error of the predictive equation using study streamgage $j$.

The MOVE.1 equations developed to estimate daily mean discharge $(Q)$ at each of the study streamgages are as follows. The form of the equation has been modified from logarithmic units so that the input and results of the equations are in arithmetic units.

1. Swift River 0.5 mile below Hobbs Brook, near Conway, N.H.:

$$
Q=0.08152 Q_{\text {ref }}^{1.142},
$$

where

$$
\begin{aligned}
& Q_{\text {ref }} \quad \text { is the daily mean discharge at Saco River near } \\
& \text { Conway, N.H. }
\end{aligned}
$$

2. Cocheco River, at Spaulding Turnpike, at Dover, N.H.:

$$
Q=4.092 Q_{\text {ref }}^{0.9094}
$$

where

$$
Q_{\text {ref }} \quad \text { is the daily mean discharge at Cocheco River }
$$
near Rochester, N.H.

3. North River above New Hampshire Route 125, near Lee, N.H.

$$
Q=2.628 Q_{\text {ref }}^{1.133}
$$

where

$$
\begin{aligned}
& Q_{r e f} \quad \text { is the daily mean discharge at Oyster River } \\
& \text { near Durham, N.H. }
\end{aligned}
$$

4. North Branch Contoocook River near Antrim, N.H.:

$$
Q=0.1590 Q_{\text {ref }}^{1.193}
$$

where

$$
\begin{gathered}
Q_{\text {ref }} \quad \text { is the daily mean discharge at Warner River at } \\
\text { Davisville, N.H. }
\end{gathered}
$$

5. Ammonoosuc River below Lisbon Dam, at Lisbon, N.H.:

$$
\begin{aligned}
Q= & 0.2136 Q_{\text {ref } 1.197}^{1.10}+0.7285 Q_{\text {ref2 } 2.9247}+0.3504_{\text {Qref }}^{0.8865+} \\
& 0.1812 Q_{\text {ref4 }}^{1.071}+0.06267_{\text {Qref5 }}^{1.138}
\end{aligned}
$$

where

$Q_{r e f 1} \quad$ is the daily mean discharge at Ammonoosuc

River at Bethlehem Junction, N.H.,

$Q_{\text {ref2 }} \quad$ is the daily mean discharge at Baker River near Rumney, N.H.,

$Q_{\text {ref3 }} \quad$ is the daily mean discharge at Upper

Ammonoosuc River near Groveton, N.H.,

$Q_{r e f 4} \quad$ is the daily mean discharge at Pemigewasset

River at Woodstock, N.H., and

$Q_{\text {ref5 }} \quad$ is the daily mean discharge at Passumpsic

River at Passumpsic, Vermont

6. Ammonoosuc River near Bath, N.H.:

$$
\begin{aligned}
Q= & 0.3763 Q_{\text {ref } 1}^{1.114}+1.177 Q_{\text {ref2 }}^{0.8574}+0.3139 Q_{\text {ref3 }}^{0.9665}+ \\
& 0.2014 Q_{\text {ref4 }} 1.058+0.09670 Q_{\text {ref5 }}^{1.075},
\end{aligned}
$$

where

$Q_{\text {refl }} \quad$ is the daily mean discharge at Ammonoosuc

River at Bethlehem Junction, N.H.,

$Q_{\text {ref2 }} \quad$ is the daily mean discharge at Baker River

near Rumney, N.H.,

$Q_{\text {ref3 }} \quad$ is the daily mean discharge at Upper

Ammonoosuc River near Groveton, N.H.,

$Q_{\text {ref } 4} \quad$ is the daily mean discharge at Pemigewasset

River at Woodstock, N.H., and

$Q_{\text {ref5 }} \quad$ is the daily mean discharge at Passumpsic

River at Passumpsic, Vt.

\section{Error Analysis of Estimated Record}

There are several measures of accuracy of a predictive equation. A common measure of the accuracy is the meansquare error between the predictions and the observations used as input data to develop the equation. However, because the observed daily mean discharge records are available for the study streamgages, a more detailed evaluation of the accuracy of the estimated daily mean discharge records developed from the MOVE.1 equations was made by using the concurrent observed daily mean discharge records of the study streamgages. This evaluation was done for the entire available record and for selected low-flow regimes. 


\section{Comparison of Mean, Maximum, Minimum, and Standard Deviation}

Table 5 shows the minimum, mean, maximum, and standard deviation of the daily mean discharge, from the concurrent observed and estimated daily mean discharge records, for each study streamgage. These values provide some indication of how well the predictions from the MOVE. 1 equations compare to the observed values. Overall, it appears that the equations overestimate, as the means of the estimated daily mean discharges are uniformly higher than the means of the observed daily mean discharges. The standard deviation results indicate that there is more spread in the estimated discharges than the observed discharges. The lowest discharge values seem to compare well, but it should be noted that the minimum estimated daily mean discharge occurred on the same date as the observed minimum daily mean discharge only for three study streamgages: the Cocheco River, at Spaulding Turnpike, at Dover, N.H.; the North River above New Hampshire Route 125, near Lee, N.H.; and the North Branch Contoocook River near Antrim, N.H.

\section{Comparison of Flow-Duration Curves}

Appendix 2 shows flow-duration curves of the observed and estimated discharge records. The flow-duration curves provide the user with an image of how well the MOVE.1 equations are representing the range and distribution of discharge at the study streamgages during the operation period and provide some insight into how well the relations will work for estimating discharge statistics over the likely range of discharges at the study streamgages. In general, the flow-duration curves indicate that discharges greater than the median discharge tend to be overestimated.

\section{Accuracy of Entire Estimated Record}

Table 6 shows the root-mean-square error (RMSE) and the Nash-Sutcliffe efficiency coefficient computed from the concurrent observed and estimated daily mean discharge record for each study site. The root-mean-square error represents the mean of the absolute distance between the observed and estimated values. A lower RMSE indicates a better fit between the observed and estimated data. The RMSE values ranged from 105 to 338 . The Nash-Sutcliffe efficiency coefficient is a measure of the predictive effectiveness of the model or equation. A value of 1 indicates that the results of the model are a perfect match to the observed data. A value equal to zero indicates that the mean of the observed values is as accurate a predictor as the model. A value less than zero indicates that the mean is more accurate as a predictor. The Nash-Sutcliffe efficiency coefficient is greater than 0.85 for four of the six MOVE. 1 equations. For the other two streamgages, the NashSutcliffe efficiency coefficient is between 0.45 and 0.60 .

The daily mean discharge records at each study streamgage were also compared on a day-to-day basis to determine the percentage of estimated daily mean discharges that were at or within $5,10,15,20$, and 25 percent of the observed daily mean discharges. These results are shown in table 7. More than 35 percent of the estimated record was

Table 5. Statistics of the observed and estimated daily mean discharge records for the six study streamgages in New Hampshire.

$\left[\mathrm{ft}^{3} / \mathrm{s}\right.$, cubic foot per second, NH, New Hampshire]

\begin{tabular}{|c|c|c|c|c|c|c|c|c|}
\hline \multirow{3}{*}{ Study streamgage } & \multicolumn{8}{|c|}{ Daily mean discharge } \\
\hline & \multicolumn{2}{|c|}{ Minimum } & \multicolumn{2}{|c|}{ Mean } & \multicolumn{2}{|c|}{ Maximum } & \multicolumn{2}{|c|}{ Standard deviation } \\
\hline & $\begin{array}{l}\text { Observed, } \\
\text { in } \mathrm{ft}^{3} / \mathrm{s}\end{array}$ & $\begin{array}{l}\text { Estimated, } \\
\text { in } \mathrm{ft}^{3} / \mathrm{s}\end{array}$ & $\begin{array}{l}\text { Observed, } \\
\text { in } \mathrm{ft}^{3} / \mathrm{s}\end{array}$ & $\begin{array}{l}\text { Estimated, } \\
\text { in } \mathrm{ft}^{3} / \mathrm{s}\end{array}$ & $\begin{array}{l}\text { Observed, } \\
\text { in } \mathrm{ft}^{3} / \mathrm{s}\end{array}$ & $\begin{array}{l}\text { Estimated, } \\
\text { in } \mathrm{ft}^{3} / \mathrm{s}\end{array}$ & $\begin{array}{l}\text { Observed, } \\
\text { in } \mathrm{ft}^{3} / \mathrm{s}\end{array}$ & $\begin{array}{l}\text { Estimated, } \\
\text { in } \mathrm{ft}^{3} / \mathrm{s}\end{array}$ \\
\hline $\begin{array}{l}\text { Swift River } 0.5 \text { mile below Hobbs } \\
\text { Brook, near Conway, NH } \\
(01064485)\end{array}$ & 23.4 & 29.1 & 294 & 311 & 2,530 & 3,970 & 359 & 457 \\
\hline $\begin{array}{l}\text { North River above NH Route } 125 \text {, } \\
\text { near Lee, NH (01073460) }\end{array}$ & 0.9 & $1.0^{\mathrm{a}}$ & 99.2 & 124 & 3,340 & 4,870 & 194 & 290 \\
\hline $\begin{array}{l}\text { North Branch Contoocook River } \\
\text { near Antrim, NH }(01084000)\end{array}$ & 0.1 & $0.5^{\mathrm{a}}$ & 101 & 124 & 1,600 & 3,120 & 144 & 218 \\
\hline
\end{tabular}

${ }^{a}$ Occurred on same date as observed minimum. 
Table 6. Root-mean-square errors and the Nash-Sutcliffe efficiency coefficients of the maintenance of variance extension, type 1, equations for the six study streamgages in New Hampshire.

[MOVE.1, maintenance of variance extension, type 1; NH, New Hampshire]

\begin{tabular}{lcc}
\hline \multicolumn{1}{c}{ Study streamgage } & \multicolumn{2}{c}{ MOVE.1 equation } \\
\cline { 2 - 3 } & $\begin{array}{c}\text { Nash-Sutcliffe } \\
\text { Root-mean- } \\
\text { square error }\end{array}$ & \begin{tabular}{c} 
efficiency coefficient \\
\hline Swift River 0.5 mile below Hobbs Brook, near Conway, NH (01064485)
\end{tabular} \\
Cocheco River, at Spaulding Turnpike, at Dover, NH (01072880) & 138 & 0.851 \\
North River above NH Route 125, near Lee, NH (01073460) & 127 & 0.903 \\
North Branch Contoocook River near Antrim, NH (01084000) & 105 & 0.568 \\
Ammonoosuc River below Lisbon Dam, at Lisbon, NH (01137940) & 338 & 0.465 \\
Ammonoosuc River near Bath, NH (01138000) & 288 & 0.884 \\
\hline
\end{tabular}

Table 7. Percentage of days the estimated daily mean discharges were at or within $5,10,15,20$, and 25 percent of the concurrent observed daily mean discharges for six study streamgages in New Hampshire.

[NH, New Hampshire]

\begin{tabular}{|c|c|c|c|c|c|}
\hline \multirow[t]{2}{*}{ Study streamgage } & \multicolumn{5}{|c|}{$\begin{array}{l}\text { Percentage of days estimated daily mean discharge was withir } \\
\text { selected percent of concurrent observed daily mean discharge }\end{array}$} \\
\hline & 5 percent & 10 percent & 15 percent & 20 percent & 25 percent \\
\hline Cocheco River, at Spaulding Turnpike, at Dover, NH (01072880) & 9.2 & 22.3 & 36.9 & 53.7 & 68.6 \\
\hline North River above NH Route 125, near Lee, NH (01073460) & 8.6 & 21.8 & 34.4 & 43.6 & 51.8 \\
\hline Ammonoosuc River near Bath, NH (01138000) & 20.0 & 37.9 & 53.4 & 66.5 & 76.5 \\
\hline
\end{tabular}

Table 8. Percentage of days the estimated daily mean discharges were within 5, 10, 15, 20, and 25 percent of the concurrent observed daily mean discharges when observed discharges were at or below the discharge exceeded 80 percent of the time for the six study streamgages in New Hampshire.

[D80, daily mean discharge exceeded 80 percent of the time; $\mathrm{ft}^{3} / \mathrm{s}$, cubic foot per second; $\mathrm{NH}, \mathrm{New}$ Hampshire]

\begin{tabular}{|c|c|c|c|c|c|c|}
\hline Study streamgage & $\begin{array}{c}\text { D80, } \\
\text { in } \mathrm{ft}^{3} / \mathrm{s}\end{array}$ & \multicolumn{5}{|c|}{$\begin{array}{c}\text { For observed discharges at or below the D80, } \\
\text { percentage of days estimated daily mean discharge was } \\
\text { within selected percent of concurrent observed } \\
\text { daily mean discharge }\end{array}$} \\
\hline Swift River 0.5 mile below Hobbs Brook, near Conway, NH (01064485) & 84.3 & 13.9 & 24.8 & 38.7 & 62.8 & 72.3 \\
\hline Cocheco River, at Spaulding Turnpike, at Dover, NH (01072880) & 44.0 & 13.1 & 30.3 & 43.4 & 52.5 & 61.6 \\
\hline North Branch Contoocook River near Antrim, NH (01084000) & 13.0 & 5.7 & 10.0 & 14.8 & 19.8 & 24.2 \\
\hline Ammonoosuc River below Lisbon Dam, at Lisbon, NH (01137940) & 258 & 27.7 & 58.8 & 74.3 & 83.1 & 90.5 \\
\hline Ammonoosuc River near Bath, NH (01138000) & 164 & 19.1 & 38.0 & 54.0 & 66.3 & 73.7 \\
\hline
\end{tabular}


within 15 percent of the observed record for four of the six study streamgages. More than half of the estimated record was within 20 percent of the observed record for the same four streamgages. More than 23 percent of the estimated record was within 15 percent of the observed record at the other two streamgages. More than 50 percent of the estimated daily mean discharges were within 25 percent of the observed daily mean discharges at all the streamgages except North Branch Contoocook River near Antrim, N.H.

\section{Accuracy of Estimated Record for Low-Flow Regimes}

The estimated and observed daily mean discharge records at each study streamgage were also compared on a day-to-day basis for the set of days when observed discharges were at or below discharges exceeded 80 percent of the time (D80) to determine the percentage of estimated record that was within $5,10,15,20$, and 25 percent of the observed record during low-flow regimes. The D80 was computed by using the observed record for the dates with concurrent estimated record (see table 4). The results are shown in table 8. At discharges less than the D80, more than 40 percent of the estimated record was within 15 percent of the observed record for four of the six study sites. The remaining two sites, at the Swift River near Conway, N.H., and North Branch Contoocook River near Antrim, N.H., had more than 38 percent and 14 percent of the estimated record at low discharges within 15 percent of the observed record, respectively.

\section{Summary}

The U.S. Geological Survey, in cooperation with the New Hampshire Department of Environmental Services, developed and evaluated the accuracy of estimated records for six discontinued streamgages on New Hampshire designated rivers. The estimated records were developed by using the maintenance of variance extension, type 1 (MOVE.1), record extension technique. Each estimated record was generated for a period of observed record at the discontinued streamgage concurrent with record at an active reference streamgage, allowing an evaluation of the accuracy of the estimated record. The following discontinued streamgages were used in the evaluation:

- 01064485, Swift River 0.5 mile below Hobbs Brook, near Conway, New Hampshire

- 01072880, Cocheco River at Spaulding Turnpike, at Dover, N.H.

- 01073460, North River above New Hampshire Route 125, near Lee, N.H.

- 01084000, North Branch Contoocook River near Antrim, N.H.
- 01137940, Ammonoosuc River below Lisbon Dam, at Lisbon, N.H.

- 01138000, Ammonoosuc River near Bath, N.H.

For four of the six study streamgages, MOVE.1 relations were developed with only one nearby reference streamgage. For the other two study streamgages, the MOVE.1 relations were developed with multiple reference streamgages. Pearson correlation coefficients describing the relations ranged from 0.863 to 0.968 .

Estimated records for four of the six study streamgages had Nash-Sutcliffe efficiency coefficients greater than 0.85 . Discharges greater than the median discharge tended to be overestimated. For four of the six streamgages, more than 35 percent of the estimated record was within 15 percent of the observed record. For the same four streamgages, more than 50 percent of the estimated record was within 20 percent of the observed record. At lower discharges (exceeded 80 percent of the time), for four of the six streamgages, more than 40 percent of the estimated record was within 15 percent of the observed record.

\section{References Cited}

Calarullo, S.J., Sullivan, S.L., and McHugh, A.R., 2018, Implementation of MOVE.1, censored MOVE.1, and piecewise MOVE.1 low-flow regressions with applications at partial-record streamgaging stations in New Jersey: U.S. Geological Survey Open-File Report 2018-1089, 20 p., accessed November 6, 2018, at https://pubs.usgs.gov/ of/2018/1089/ofr20181089.pdf.

Granato, G.E., 2009, Computer programs for obtaining and analyzing daily mean streamflow data from the U.S. Geological Survey National Water Information System Web Site: U.S. Geological Survey Open-File Report 2008-1362, 123 p., accessed November 5, 2018, at http://newengland.water.usgs.gov/dev/g1/Software/ Streamflow/index.html.

Hirsch, R.M., 1979, An evaluation of some record reconstruction techniques: Water Resources Research, v. 15, no. 6, p. 1781-1790. [Also available at https://doi.org/10.1029/ WR015i006p01781.]

Hirsch, R.M., 1982, A comparison of four streamflow record extension techniques: Water Resources Research, v. 18, no. 4, p. 1081-1088. [Also available at https://doi.org/10.1029/WR018i004p01081.] 


\section{A Record Extension Technique for Estimating Discharge at Selected Stream Sites in New Hampshire}

Homer, C., Dewitz, J., Fry, J., Coan, M., Hossain, N., Larson, C., Herold, N., McKerrow, A., VanDriel, J.N., and Wickham, J., 2007, Completion of the 2001 National Land Cover Database for the conterminous United States: Photogrammetric Engineering and Remote Sensing, v. 73, no. 4, p. 337-341.

Matalas, N.C., and Jacobs, B., 1964, A correlation procedure for augmenting hydrologic data: U.S. Geological Survey Professional Paper 434-E, p. E1-E7, accessed May 9, 2019, at http://pubs.er.usgs.gov/publication/pp434E.

National Climatic Data Center, 2018, Data tools-19812010 normals: National Oceanic and Atmospheric Administration dataset, accessed November 1, 2018, at http://www.ncdc.noaa.gov/cdo-web/datatools/normals.

New Hampshire Department of Environmental Services, 2018, Designated rivers: New Hampshire Department of Environmental Services web page, accessed November 5, 2018, at https://www.des.nh.gov/organization/divisions/water/wmb/ rivers/desigriv.htm.
New Hampshire State Library, 2018, Fast facts, New Hampshire almanac: State of New Hampshire web page, accessed November 1, 2008, at http:/www.nh.gov/almanac/ fast-facts.htm/.

Riggs, H.C., 1972, Low-flow investigations: U.S. Geological Survey Techniques of Water-Resources Investigations, book 4, chap. B1, 18 p., accessed November 1, 2018, at https://pubs.usgs.gov/twri/twri4b1/pdf/twri_4-B1_a.pdf.

U.S. Climate Data, 2018, Climate New HampshireTemperature, rainfall, and average: U.S. Climate Data database, accessed November 1, 2018, at http://www.usclimatedata.com/climate/new-hampshire/ united-states/3199.

U.S. Geological Survey, 2018, USGS water data for the Nation: U.S. Geological Survey National Water Information System database, accessed November 1, 2018, at https://doi.org/10.5066/F7P55KJN. 
Appendixes 1-2 


\section{Appendix 1. Plots of Discharge Measurements at Study Streamgages and Concurrent Daily Mean Discharge at Reference Streamgages}

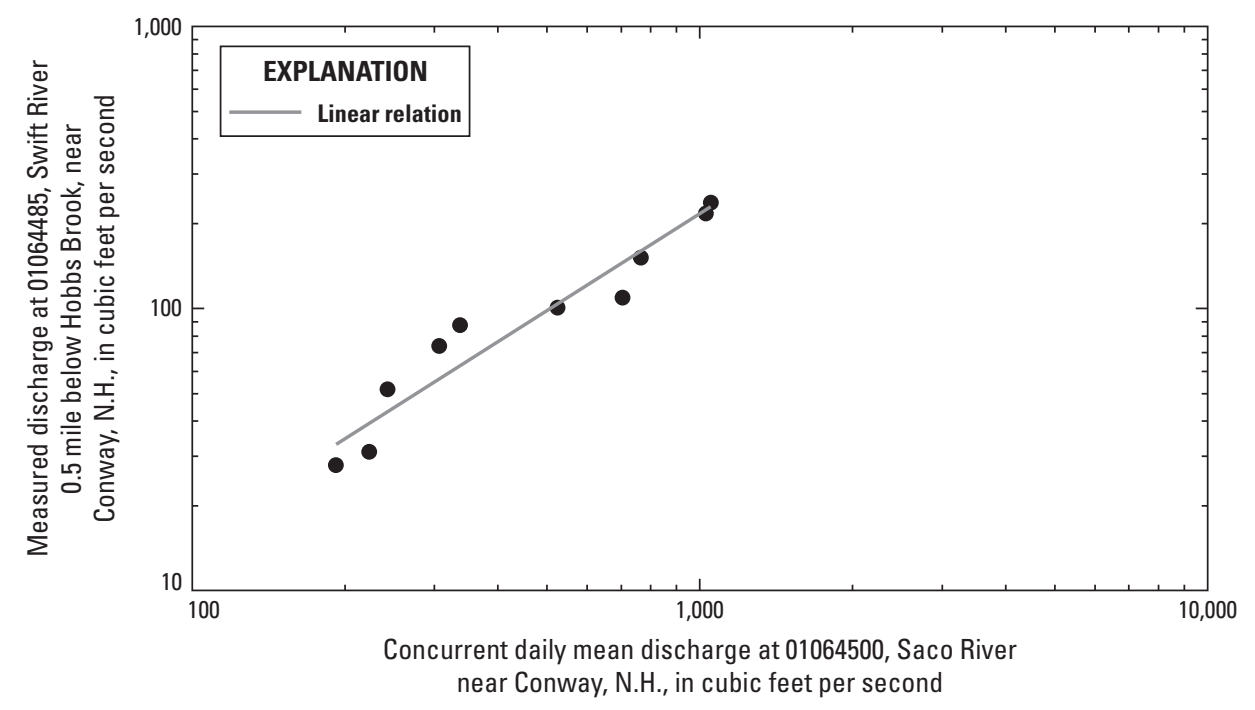

Figure 1.1. Plot of measured discharge at study streamgage 01064485 , Swift River 0.5 mile below Hobbs Brook, near Conway, New Hampshire, and concurrent daily mean discharge at reference streamgage 01064500, Saco River near Conway, N.H., with the maintenance of variance extension, type 1, relation line.

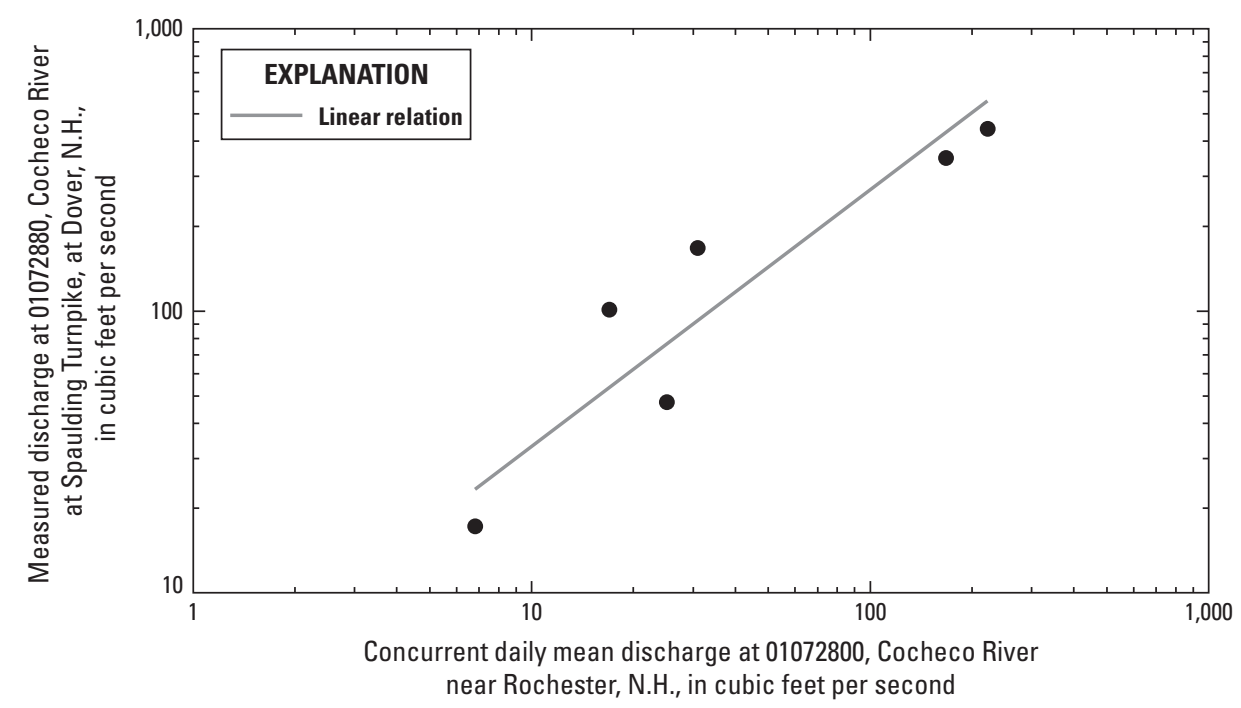

Figure 1.2. Plot of measured discharge at study streamgage 01072880, Cocheco River at Spaulding Turnpike, at Dover, New Hampshire, and concurrent daily mean discharge at reference streamgage 01072800 , Cocheco River near Rochester, N.H., with the maintenance of variance extension, type 1, relation line. 


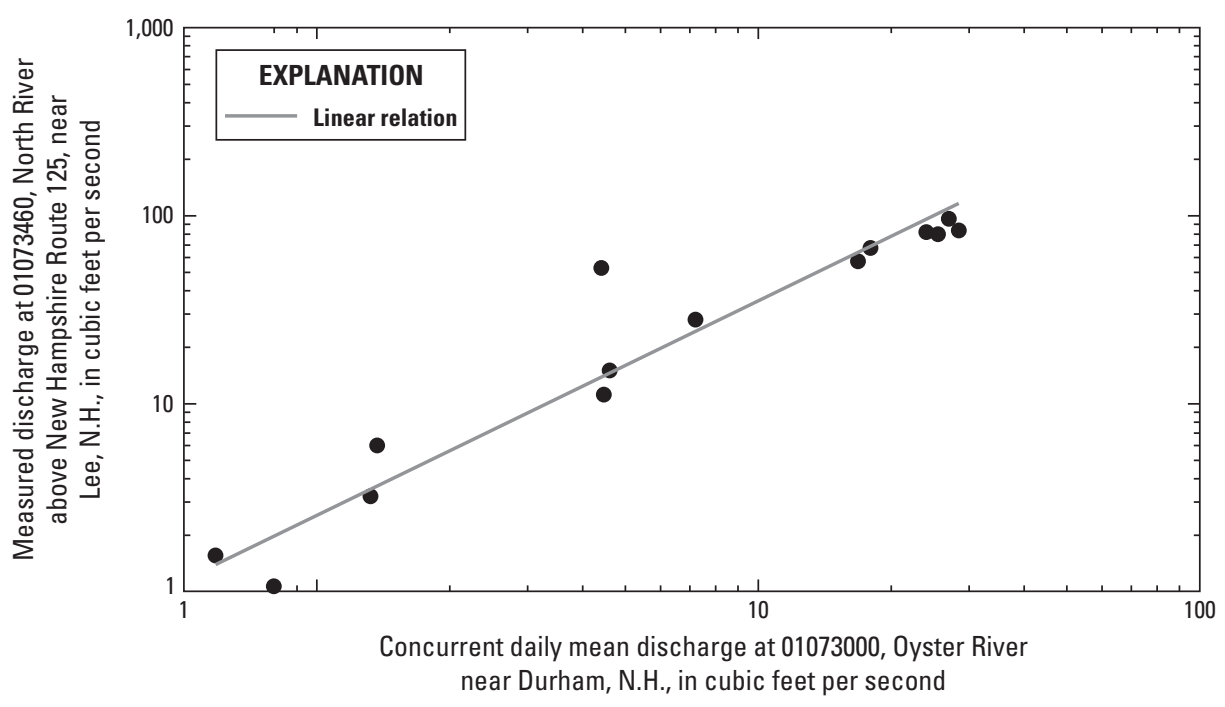

Figure 1.3. Plot of measured discharge at study streamgage 01073460 , North River above New Hampshire Route 125, near Lee, New Hampshire, and concurrent daily mean discharge

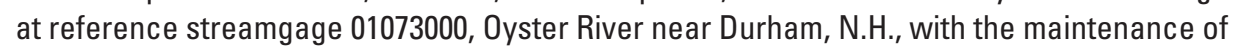
variance extension, type 1, relation line.

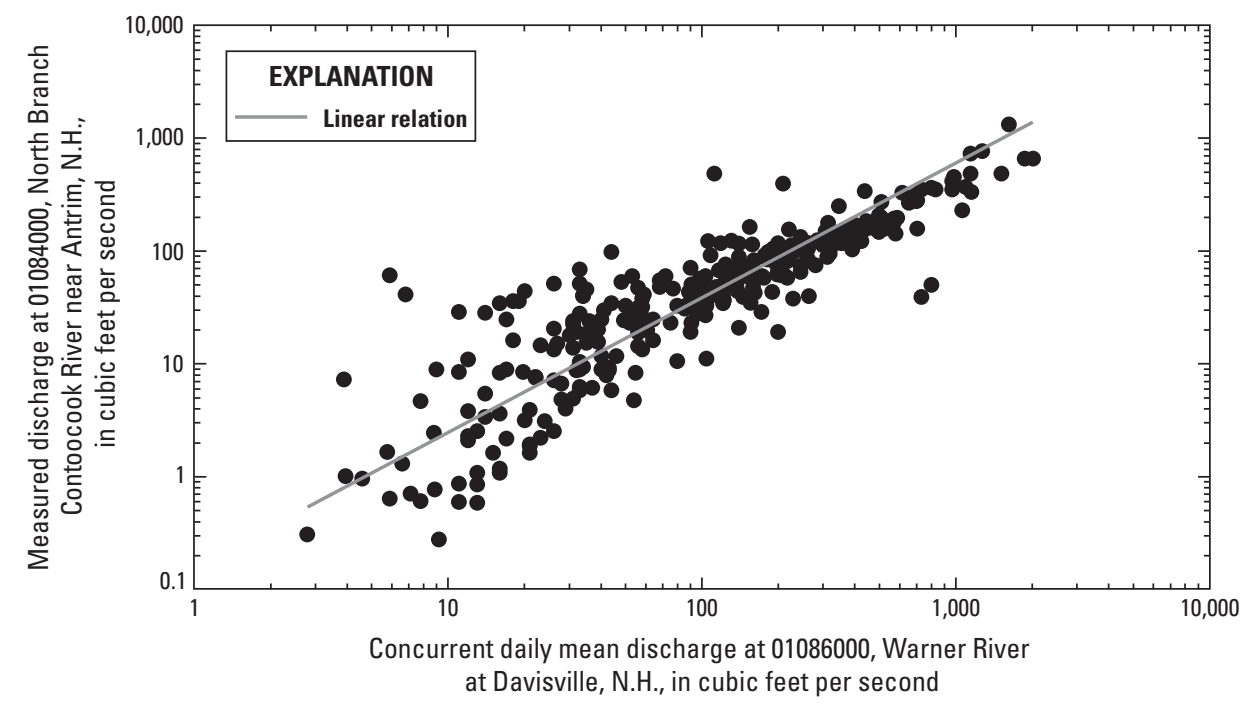

Figure 1.4. Plot of measured discharge at study streamgage 01084000, North Branch Contoocook River near Antrim, New Hampshire, and concurrent daily mean discharge at reference streamgage 01086000 , Warner River at Davisville, N.H., with the maintenance of variance extension, type 1, relation line. 


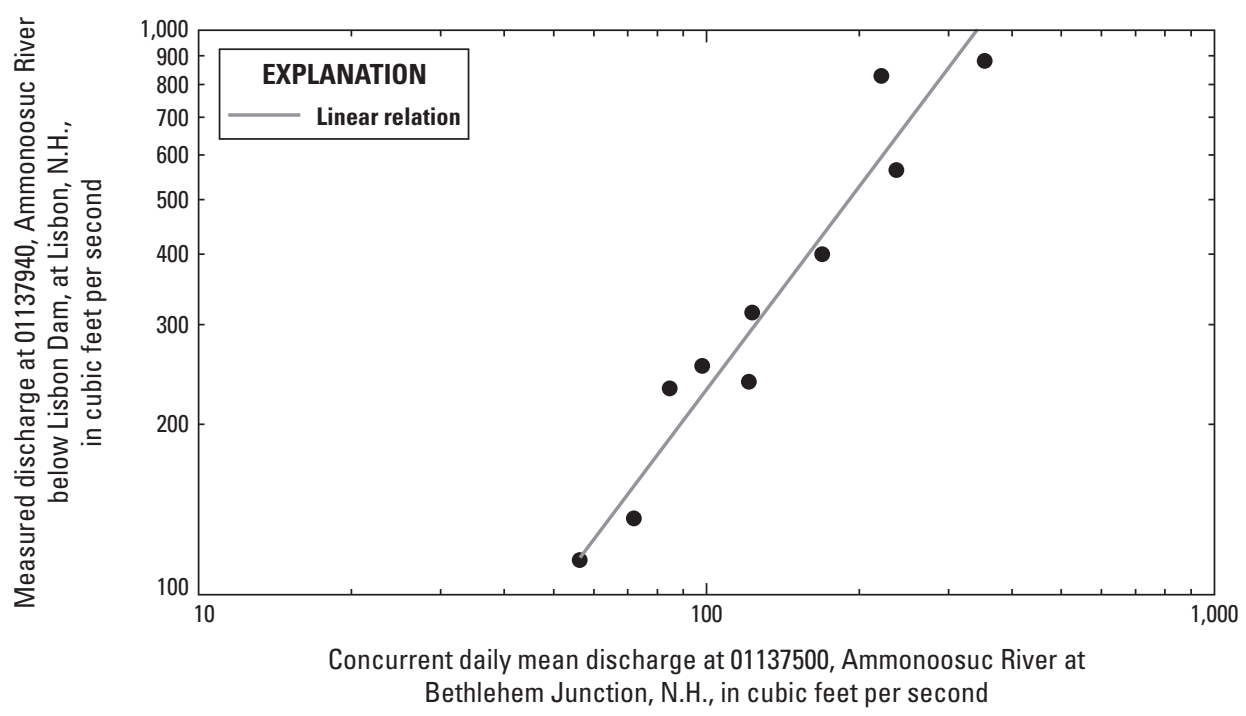

Figure 1.5. Plot of measured discharge at study streamgage 01137940, Ammonoosuc River below Lisbon Dam, at Lisbon, New Hampshire, and concurrent daily mean discharge at reference streamgage 01137500, Ammonoosuc River at Bethlehem Junction, N.H., with the maintenance of variance extension, type 1, relation line.

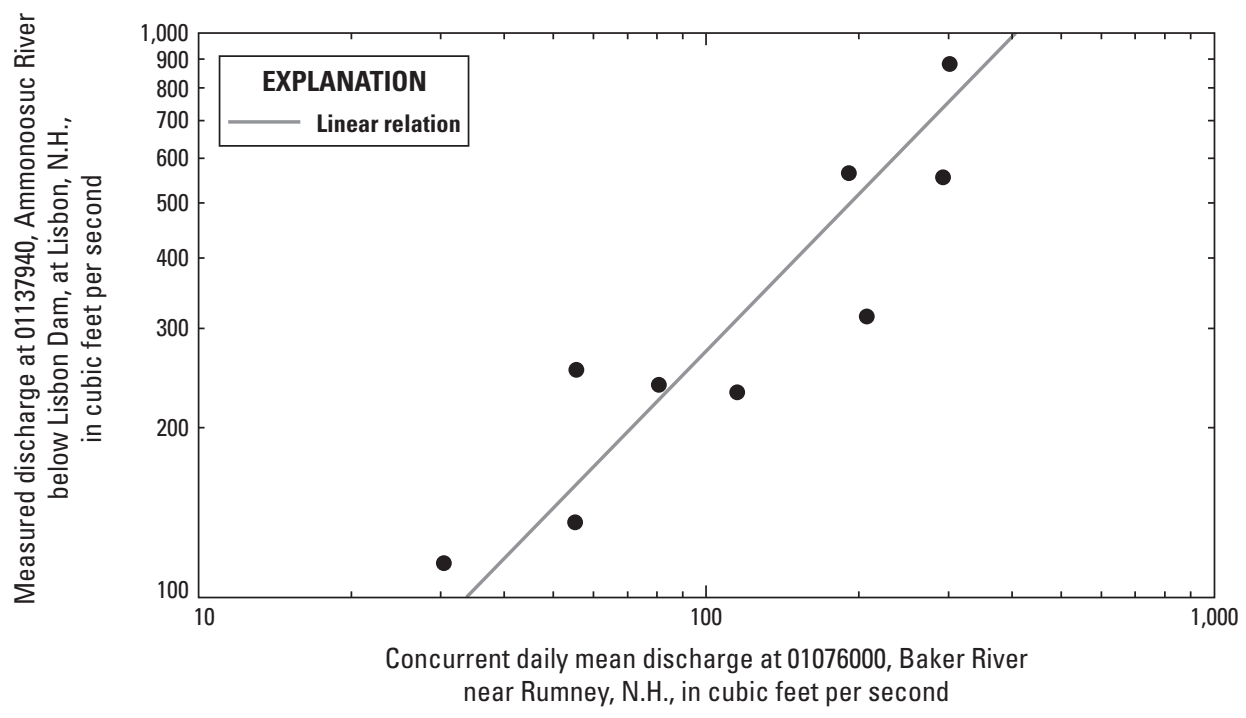

Figure 1.6. Plot of measured discharge at study streamgage 01137940, Ammonoosuc River below Lisbon Dam, at Lisbon, New Hampshire, and concurrent daily mean discharge at reference streamgage 01076000, Baker River near Rumney, N.H., with the maintenance of variance extension, type 1, relation line. 


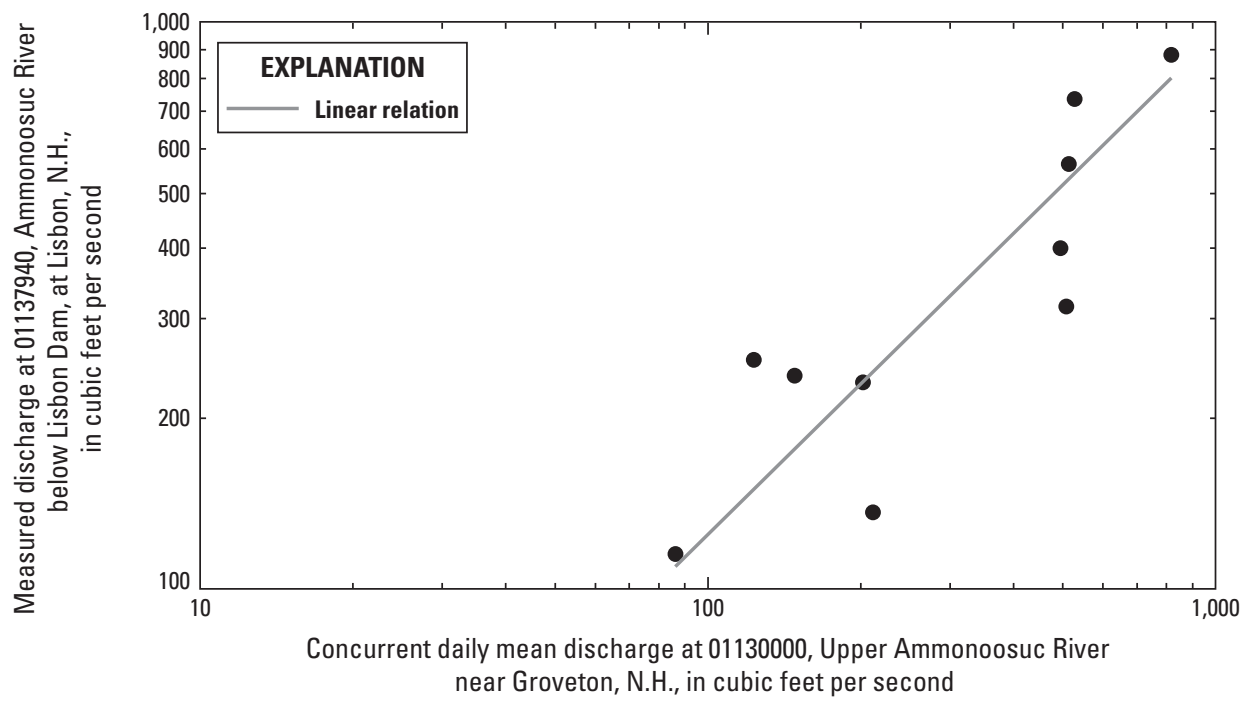

Figure 1.7. Plot of measured discharge at study streamgage 01137940, Ammonoosuc River below Lisbon Dam, at Lisbon, New Hampshire, and concurrent daily mean discharge at reference streamgage 01130000, Upper Ammonoosuc River near Groveton, N.H., with the maintenance of variance extension, type 1 , relation line.

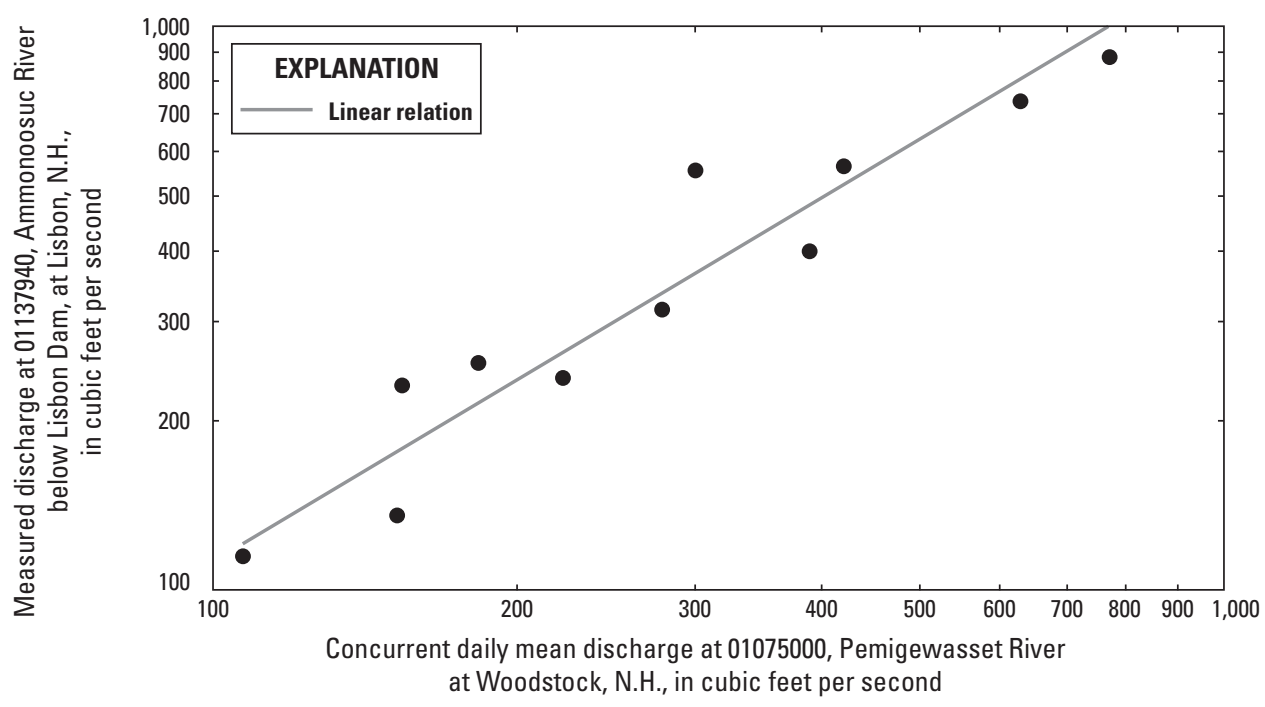

Figure 1.8. Plot of measured discharge at study streamgage 01137940, Ammonoosuc River below Lisbon Dam, at Lisbon, New Hampshire, and concurrent daily mean discharge at reference streamgage 01075000, Pemigewasset River at Woodstock, N.H., with the maintenance of variance extension, type 1 , relation line. 


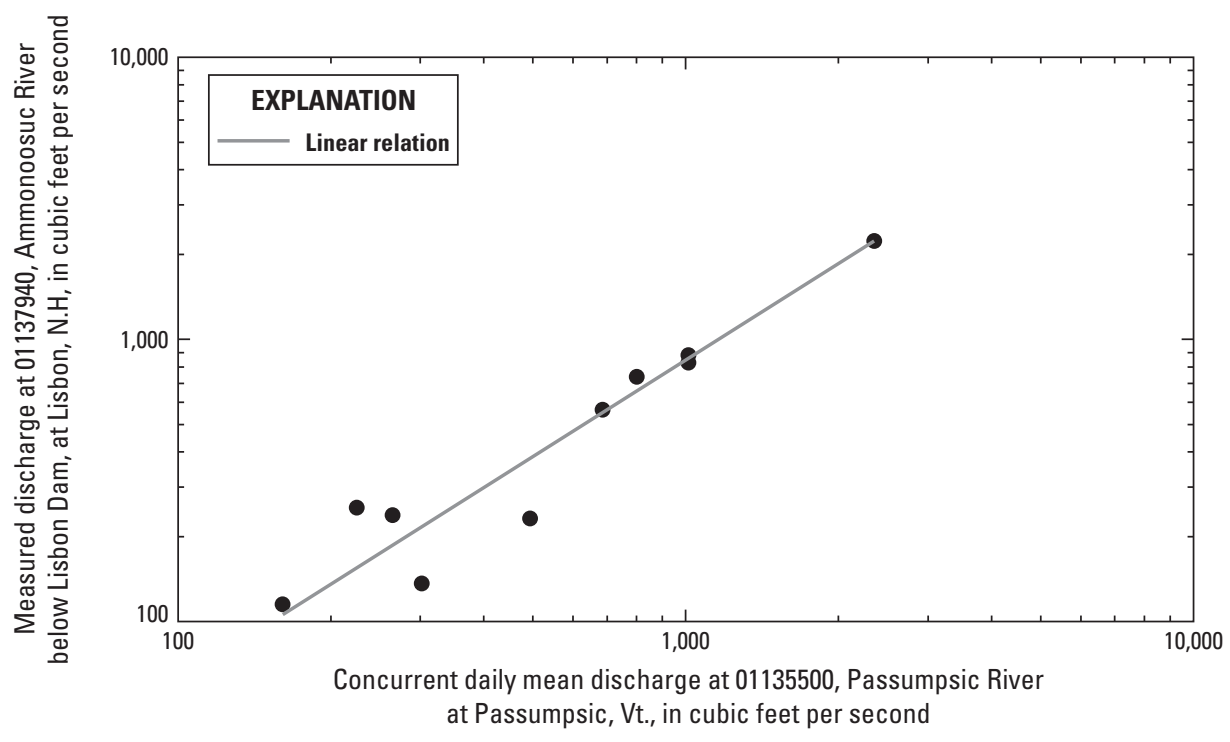

Figure 1.9. Plot of measured discharge at study streamgage 01137940, Ammonoosuc River below Lisbon Dam, at Lisbon, New Hampshire, and concurrent daily mean discharge at reference streamgage 01135500, Passumpsic River at Passumpsic, Vermont, with the maintenance of variance extension, type 1, relation line.

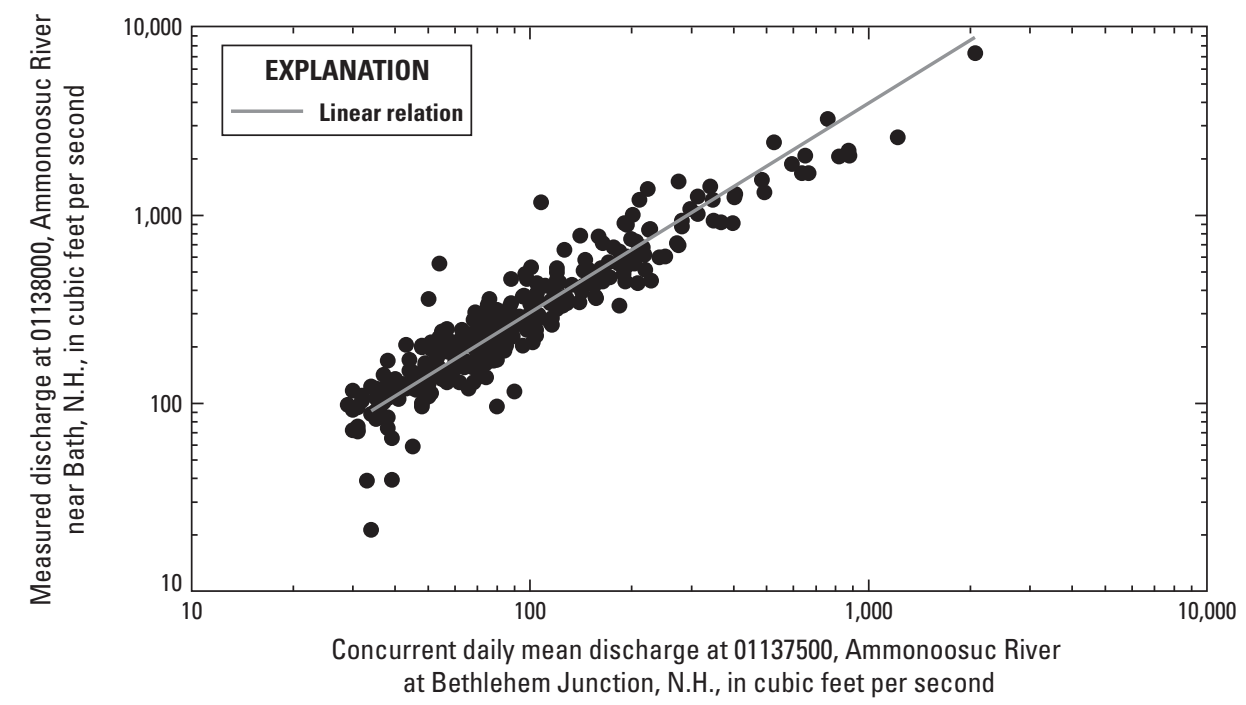

Figure 1.10. Plot of measured discharge at study streamgage 01138000 , Ammonoosuc River near Bath, New Hampshire, and concurrent daily mean discharge at reference streamgage 01137500, Ammonoosuc River at Bethlehem Junction, N.H., with the maintenance of variance extension, type 1, relation line. 


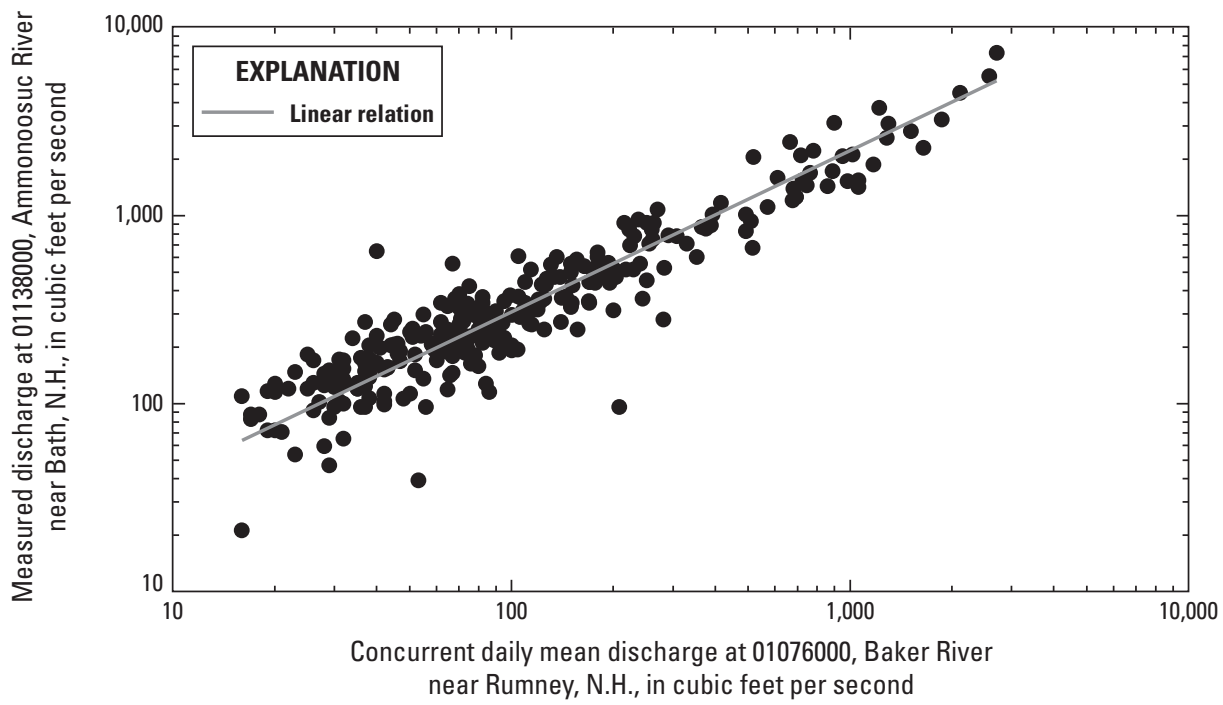

Figure 1.11. Plot of measured discharge at study streamgage 01138000, Ammonoosuc River near Bath, New Hampshire, and concurrent daily mean discharge at reference streamgage 01076000, Baker River near Rumney, N.H., with the maintenance of variance extension, type 1, relation line.

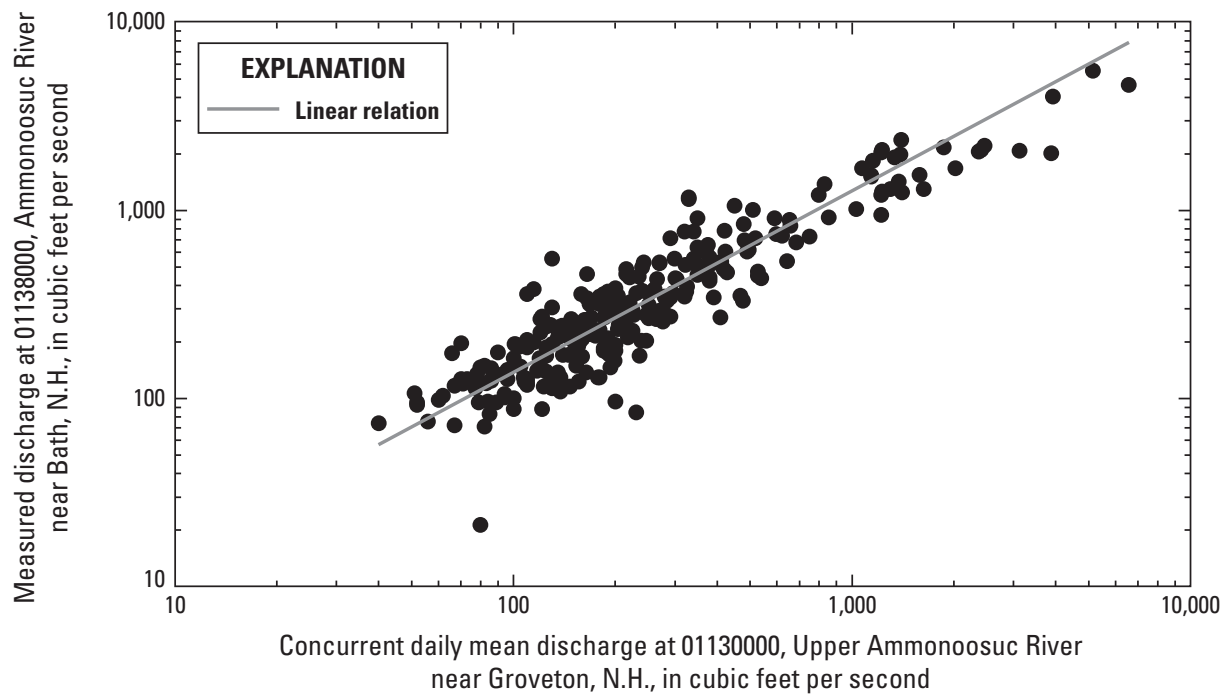

Figure 1.12. Plot of measured discharge at study streamgage 01138000, Ammonoosuc River near Bath, New Hampshire, and concurrent daily mean discharge at reference streamgage 01130000, Upper Ammonoosuc River near Groveton, N.H., with the maintenance of variance extension, type 1, relation line. 


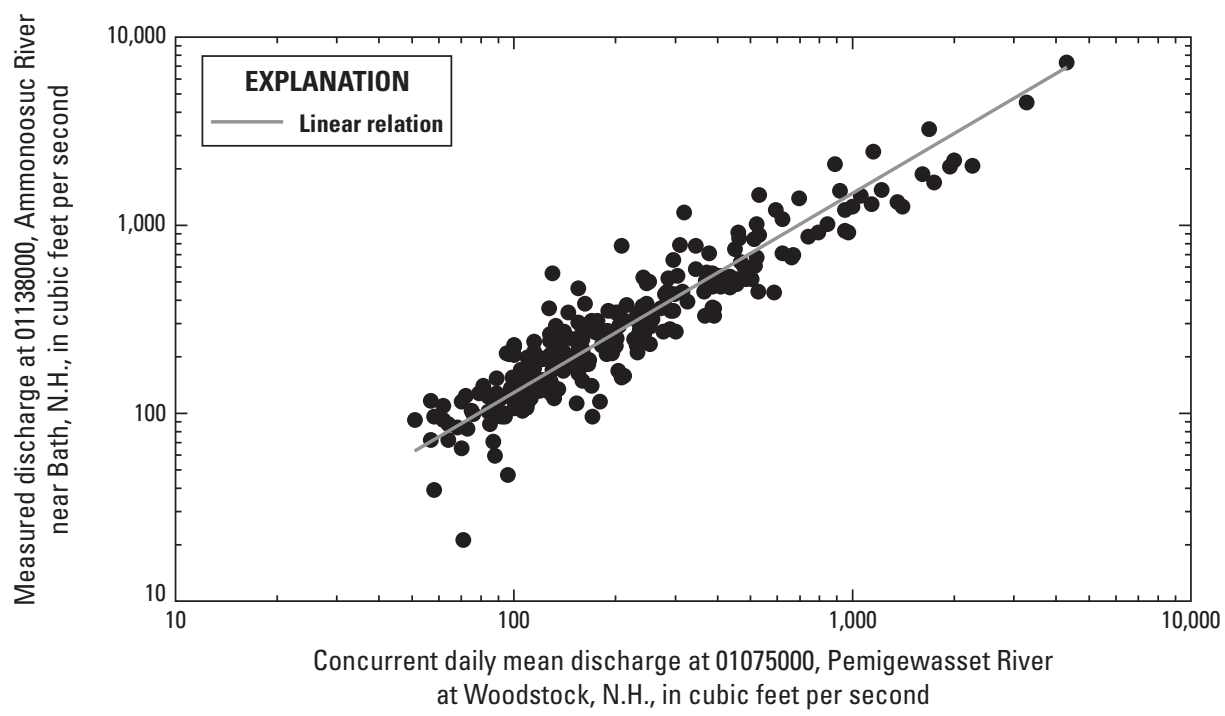

Figure 1.13. Plot of measured discharge at study streamgage 01138000, Ammonoosuc River near Bath, New Hampshire, and concurrent daily mean discharge at reference streamgage 01075000, Pemigewasset River at Woodstock, N.H., with the maintenance of variance extension, type 1, relation line.

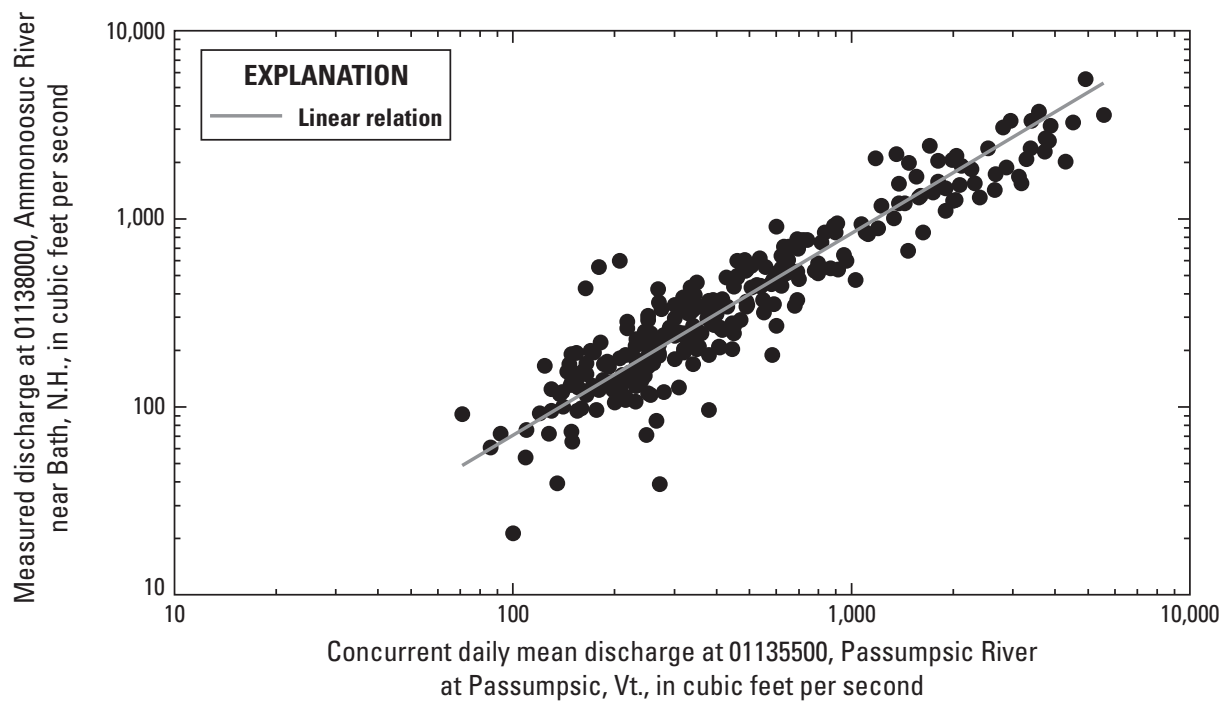

Figure 1.14. Plot of measured discharge at study streamgage 01138000, Ammonoosuc River near Bath, New Hampshire, and concurrent daily mean discharge at reference streamgage 01135500, Passumpsic River at Passumpsic, Vermont, with the maintenance of variance extension, type 1, relation line. 


\section{Appendix 2. Flow-Duration Curves of the Observed and Estimated Daily Mean Discharges at Study Streamgages}

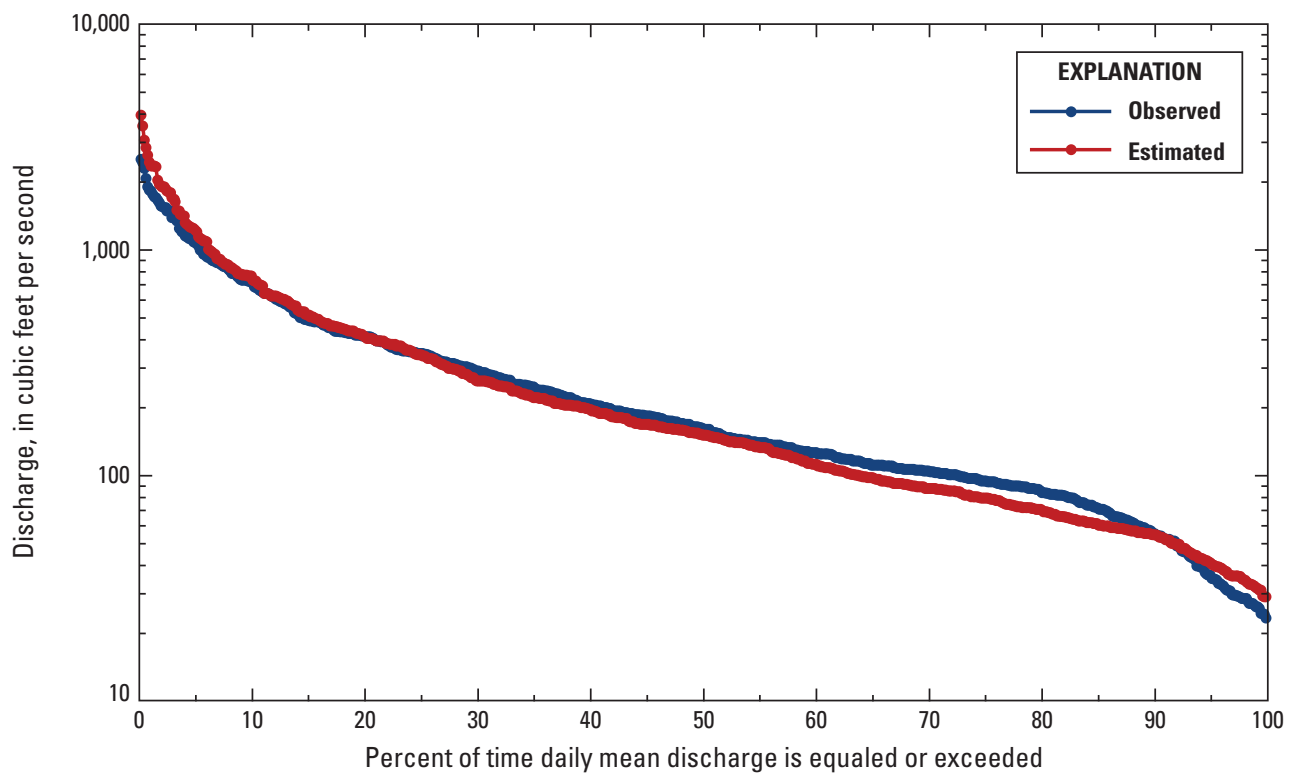

Figure 2.1. Flow-duration curves of the observed and estimated daily mean discharges for streamgage 01064485, Swift River 0.5 mile below Hobbs Brook, near Conway, New Hampshire.

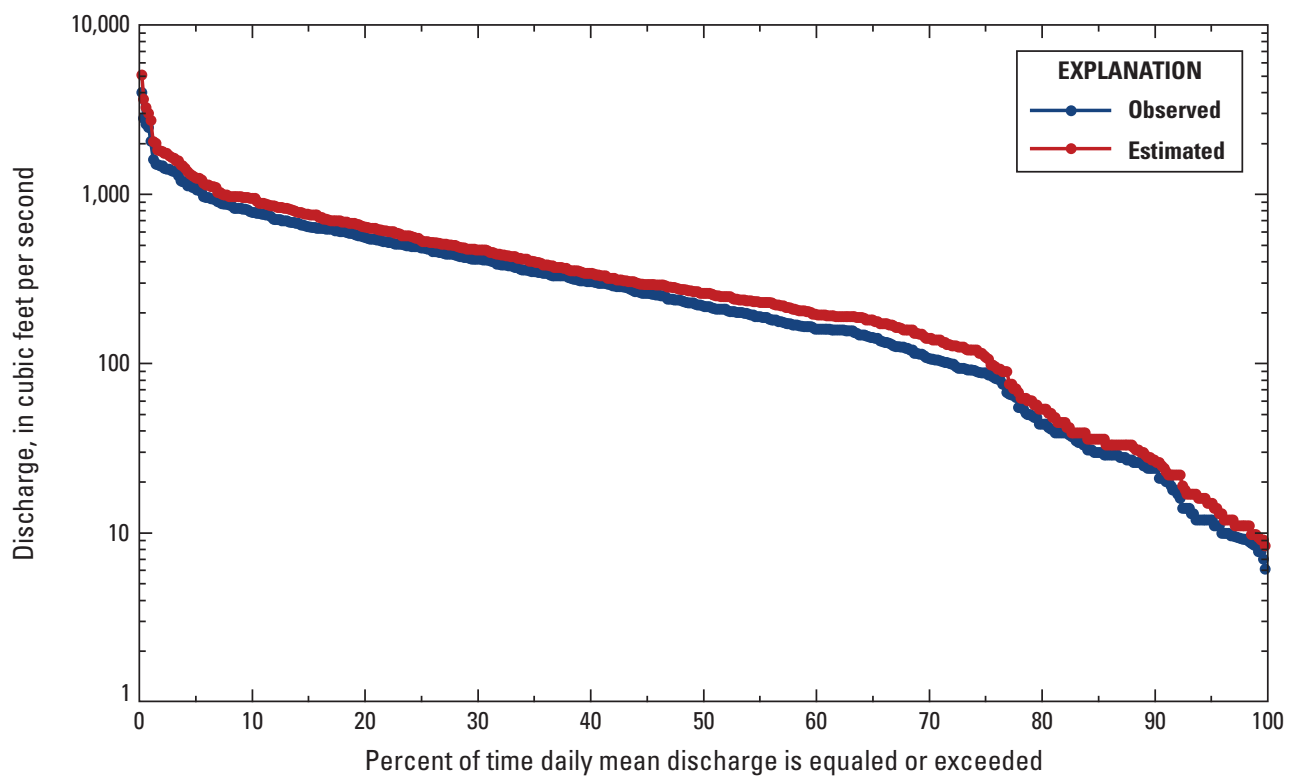

Figure 2.2. Flow-duration curves of the observed and estimated daily mean discharges for streamgage 01072880, Cocheco River, at Spaulding Turnpike, at Dover, New Hampshire. 


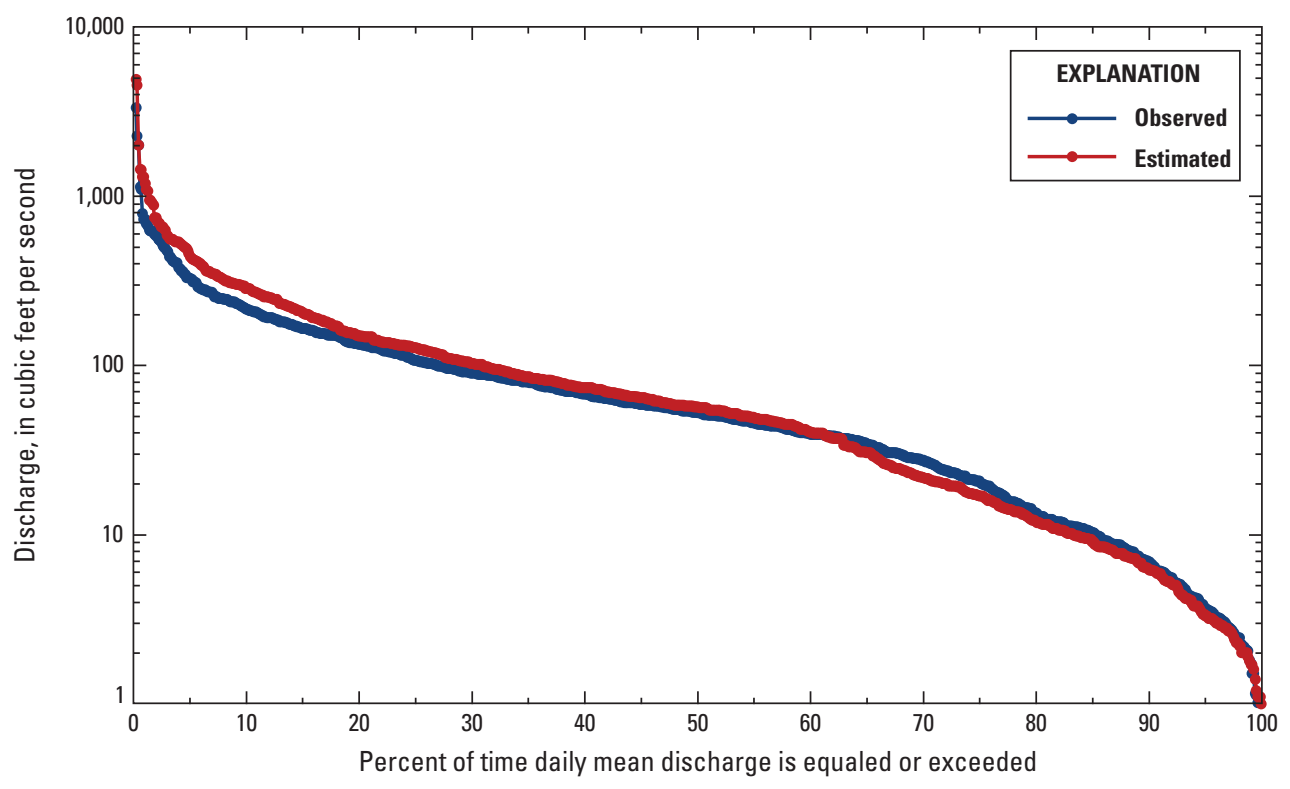

Figure 2.3. Flow-duration curves of the observed and estimated daily mean discharges for streamgage 01073460 North River above New Hampshire Route 125, near Lee, New Hampshire.

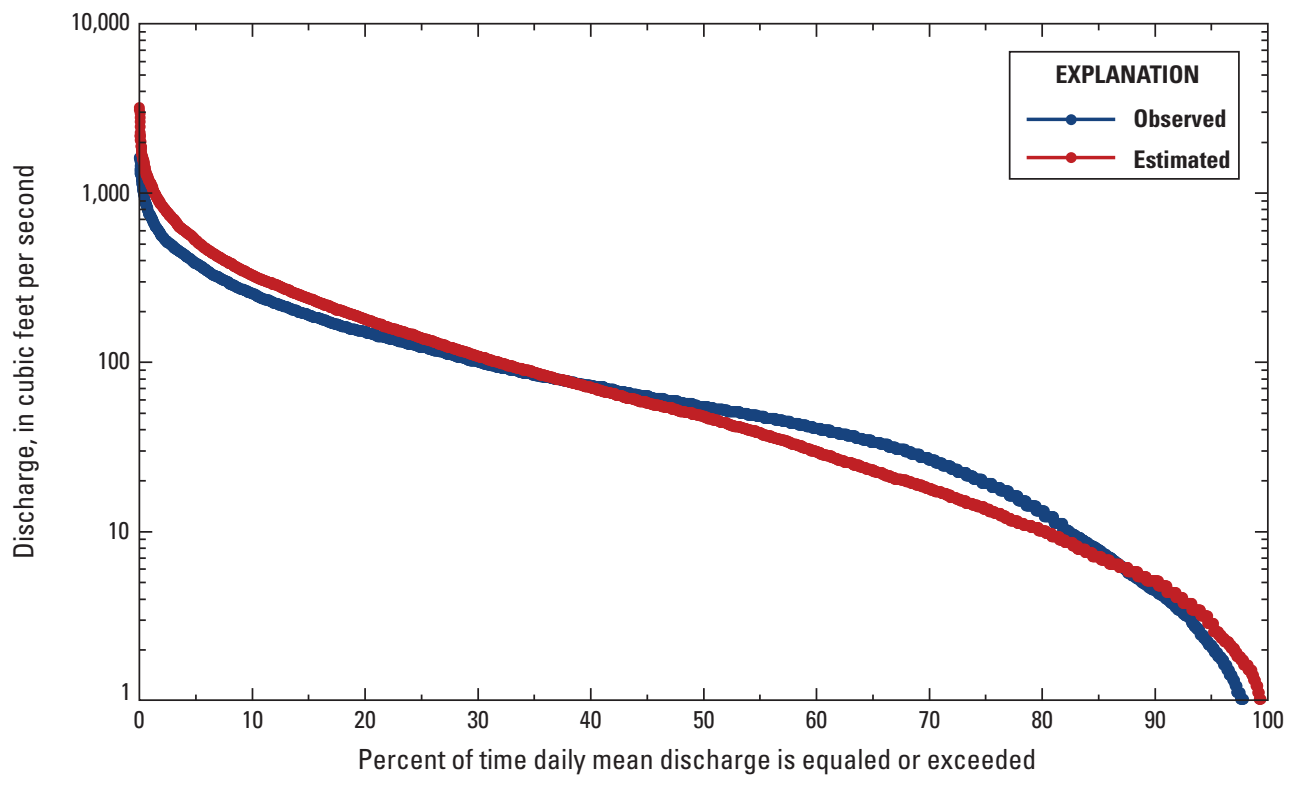

Figure 2.4. Flow-duration curves of the observed and estimated daily mean discharges for streamgage 01084000 North Branch Contoocook River near Antrim, New Hampshire. 


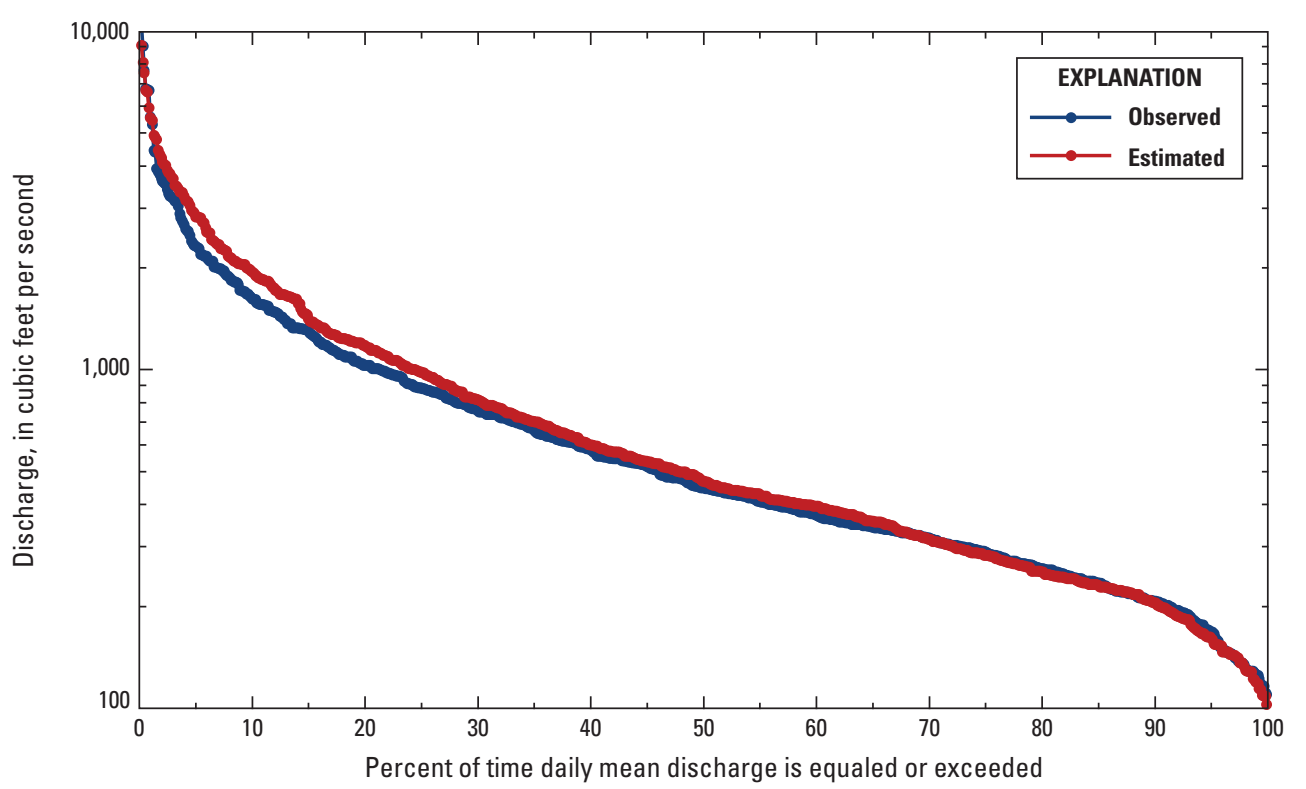

Figure 2.5. Flow-duration curves of the observed and estimated daily mean discharges for streamgage 01137940, Ammonoosuc River below Lisbon Dam, at Lisbon, New Hampshire.

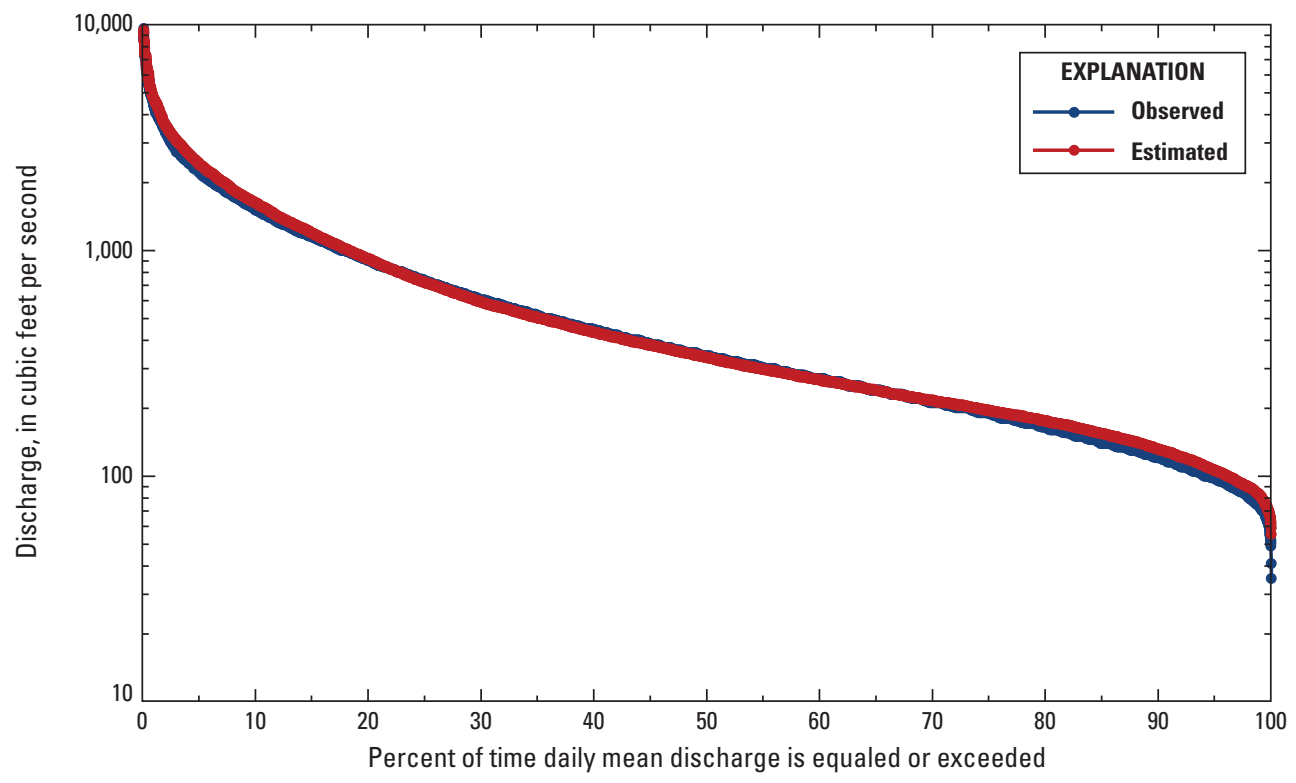

Figure 2.6. Flow-duration curves of the observed and estimated daily means discharges for streamgage 01138000, Ammonoosuc River near Bath, New Hampshire. 

For more information about this report, contact: Director, New England Water Science Center U.S. Geological Survey

331 Commerce Way, Suite 2

Pembroke, NH 03275

dc_nweng@usgs.gov

or visit our website at

https://newengland.water.usgs.gov

Publishing support provided by the Pembroke Publishing Service Center 
岂.

容

믕.

을

흐

$\stackrel{2}{\vec{c}}$

赵

$\frac{\Phi}{\Phi}$

疍

宩

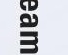

号

蛋

$\Xi$

罗

兑

옹

용 